\title{
Psikolojik Danışman Adaylarıyla Çözüm Odaklı Grupla Psikolojik Danışmanın Çözüm Odaklı Eğilim ve Otomatik Düşüncelere Etkisi
}

\author{
DOI: 10.26466/opus.693205 \\ * \\ Rezzan Gündoğdu * \\ * Doç. Dr. Aksaray Üniversitesi, Eğitim Fakültesi, Merkez/Aksaray \\ E-Posta: rezgundogdu@gmail.com \\ ORCID: $\underline{0000-0002-1220-9157}$
}

\begin{abstract}
Öz
Bu araştırma, çözüm odaklı kısa süreli grupla psikolojik danışmanın (ÇOKSPD), Rehberlik ve Psikolojik Danışmanlık (RPD) öğrencilerinin çözüm odaklı eğilimlerini ve otomatik düşünceleri üzerindeki etkilerini incelemek amacina yönelik öntest-sontest-izleme testi ile deney-kontrol-plasebo gruplariyla yar deneysel bir araştırmadır. Araştırmanın örneklemi 2018-2019 eğitim-öğretim senesi Aksaray Üniversitesi, Eğitim Fakültesi-RPD programındaki öğrenim gören öğrencilerden oluşmaktadır. Araştırmanın bağımlı değişkenlerini ölçmek için Grant, Cavanagh, Kleitman, Spence, Lakota ve Yu (2012) tarafindan geliştirilen ve Şanal-Karahan ve Hamarta (2015) tarafindan Türkçe'ye çevrilen "Çözüm Odaklı Envanter" kullanılmıştır. Ardından Hollon ve Kendall (1980) tarafından geliştirilen ve farklı zamanlarda Aydın ve Aydın (1990) ile Şahin ve Şahin (1992) tarafindan tarafindan Türkçe'ye uyarlanmış "Otomatik Düşünceler Ölçeği" kullanılmıştır. Paket program SPSS 18 ile veriler çözümlenmiştir. Elde edilen bulgular incelendiğinde, grupların kendi içlerindeki farkları ortaya çıkarmak için tekrarlı ölçümler için Wilcoxon İşaretli Sıralar Testi yapılmıştır. Deney, kontrol ve plasebo grupları arasında öntest-sontest-izleme test puanları arasındaki farkı ortaya çıkarmak için ise Mann Whitney$U$ testi yapılmıştır. Altı hafta süren ÇOKSPD'nın sonunda deney grubunun otomatik düşünceler ve çözüm odaklı envanter puanlarının ön testten son teste doğru değiştiği görüllmüsstür. Dört ay sonra alınan izleme ölçümlerinde ise deney grubu lehine otomatik düşünceler puanlardaki değişimin benzer şekilde devam ettiği bulunmuştur. Çözüm odakl envanter puanlarında ise plasebo ve kontrol grubu lehine değişimler olduğu bulunmuştur. Elde edilen sonuçlara dayanarak programın özellikle otomatik düşünceler puanlarının düşmesinde etkili olduğu söylenebilir.
\end{abstract}

Anahtar Kelimeler: Çözüm odaklı kısa süreli grupla psikolojik danışma, psikolojik danışman adayları, otomatik düşünceler 


\title{
The Effect of Solution-Focused Group Counseling with Psychological Counselor Candidates on Solution-Focused Tendency and Automatic Thoughts
}

\begin{abstract}
The purpose of this study was to examine the effects of solution-focused brief group psychological counseling (SFBGC) on Guidance and Psychological Counseling students' solution-focused tendencies and automatic thoughts. The study employed a pretest posttest follow-up test design, a quasiexperimental design. The sample of the research consists of students studying in the Guidance and Psychological Counseling Department in the 2018-2019 academic year at the Faculty of Education at Aksaray University. "Solution-Focused Inventory" developed by Grant, Cavanagh, Kleitman, Spence, Lakota ve Yu (2012) and by Karahan-Şanal and Hamarta (2015) adapted to Turkish. Afterwards, "Automatic Thoughts Questionnaire", developed by Hollon ve Kendall (1980) and adapted to Turkish by Aydin ve Aydin (1990), and Şahin ve Şahin (1992) were administered. The data were analyzed with SPSS 18 package program. Mann-Whitney U Test was used to reveal the difference between the pretest, posttest and follow-up test scores of the experimental, control and placebo groups, and Wilcoxon Signed Rank Test was utilised to reveal the differences within the groups for repeated measurements. End of the 6-week, it was observed that the automatic thoughts and solution-focused inventory scores of the experimental group changed from pre-test to post-test. In the monitoring measurements taken 4 months later, it was found that the changes in automatic thoughts scores in favor of the experimental group continued similarly. It was found that there were changes in solution-focused inventory scores in favor of placebo and control group. The results have shown that the program is especially effective in decreasing the automatic thoughts scores.
\end{abstract}

Keywords: Solution-focused brief group counseling, Psychological counseling candidates, Automatic Thoughts 


\section{Giriş}

Günümüz dünyasına uyum sağlamaya, var olmaya, ruhen ve bedenen sağlıklı olmaya çalışan insanoğlu, kendi çözüm yollarını bulmak, kendini ve dünyayı anlamak, daha anlamlı bir hayat yaşamak için, yeni düşünce şekillerini geliştirmeye ve farklı çözümler denemeye istekli görünmektedir. Bunun için arayışları ve çabaları olan bireylere yardım eden psikolojik danışma ve/veya terapi süreçleri farklı yaklaşımlar üzerinde çalışmaktadır. Çözüm odaklı yaklaşım bunlardan biri olup, insanların kaynaklarına ve kendini toparlama gücüne dayalı aynı zamanda amaçlı ve olumlu değişimin izinden hareket ederek, bunları danışanın nasıl kullanabileceğine gösteren bir kuramdır. Bu yaklaşıma ilgi artmakla beraber, yaklaşımın uygulandığı araştırma sayısı azdır (Grant vd., 2012).

Temel felsefesini "Bozulmamışı onarma.", " İşleyen çözüm yollarını uygulamaya devam et." ve "İşlemeyen çözüm yollarında ısrarcı olma ve farklı çözüm yolların dene." ilkeleriyle üç ana dinamik üzerine yapılandıran Çözüm Odaklı Kısa Süreli Psikolojik Danışma Yaklaşımı (Sklare, 1997), bireyin kendi kaynakları ile kendini toparlama gücüne odaklanan bir yaklaşım olarak 1970'lerden bu yana işlerliğini sürdürmektedir. Yaklaşımın temel sayıltısl; çözümlere odaklanmak, danışanı sorunları üzerine düşünmek yerine bu sorunların çözümleri üzerine düşünme ve konuşmaya yönlendirmektir (Gingerich ve Wabeke, 2001). Pozitif ve etkin bir amaç belirlemek, problemlerin çözümü için bir ön koşul olarak düşünülmekte (Weiner-Davis, 1996), bu bağlamda bireyi amaçlı ve olumlu değişimin izinden gitmeye ve bunları nasıl kullanabileceğine dair cesaretlendiren yaklaşım (Grant vd., 2012), danışanın gelecek yönelimli ve düşünce üreten bir birey olmasına dönük de çalışmaktadır (Doğan, 1999). Bu bakış açısıyla danışan, aktif bir rol üstlenirken kendi kaynakları ile sorunlarının çözümlerini bulabileceği gücünün kendisinde var olduğuna inanmakta (MacDonald, 2007); sorumluluk almakta ve çözüme ulaşmada daha istekli gözükmektedir (Seligman, 2006). Yaklaşıma göre süreç, "geçmiş" ve "şu an" yerine daha çok sorunun çözülebileceği tek zaman dilimi olan "gelecek" üzerine yapılandırılmakta; danışanın ise sorun üzerine konuşması yerine çözüm üzerine konuşması ve düşünmesi rehber görevi üstlenen danışman tarafından sağlanmaktadır (Quick, 1996). 
Çözüm odaklı düşüncenin yapılandırılmasında ilk alt boyut, hedefe yönelimdir. Hedefe yönelim, çözümü yapılandırmak için öz düzenlemenin etkin kullanımı ile hedef belirleme ve hedefin uygulamasının birleşimini içermektedir. İkinci alt boyutla ise bireydeki potansiyeli yakalamaya dönük, bireyde var olan güçleri ve kaynakları kullanmayı içeren düşüncenin kaynaklarmı harekete geçirme vurgulanmaktadır (Grant, 2011). Üçüncü alt boyut, ortaya konan problemden dişsal bir ayrılma olarak problemden ayırma sürecini ifade ederken bu boyut, çözüme odaklanmak için bireyi özgür kılmakta ve bireyin hedeflerine yönelmesi için gereken önemli bir unsuru karşılamaktadır (Grant, 2011).

Çözüm odaklı yaklaşım, danışanın kaynaklarına vurgu yapar ve danışanların problemlerini çözmek için istedikleri sonuçlara ulaşmalarını amaçlar (O'Connel, 2001). Danışana teşhis koymak yerine bireyi çözüme götürecek işe yarar, işlevsel davranışları ortaya çıkarır. İşe yarar olmayanların yerine farklı çözüm yolların deneyebilme cesareti verilir (Walter ve Peller, 1992).Bireyin kendi kaynaklarını görebilmesi, işlevsel davranışlar sergileyebilmesi, problemleri çözülebilmesi için farklı yolları deneyebilecdeği akıl etmesi, onun düşünce sistemi/yapısı ile yakından ilgilidir.

Bu noktada araştırmanın önemli bir diğer kavramı olan otomatik düşünceleri ele alacak olursak, Beck bireyin bilişsel yapısını kavramlaştırırken, bilişleri iki ana başlıkta inceler; otomatik düşünceler ve şemalar (Türkçapar, 2018). Otomatik düşünceler yapılan bir araştırmada, sıradan bir kişinin bir gün içinde uyanık olduğu yaklaşık 16 saatlik zaman dilimi içinde zihninden ortalama 40.000 farklı düşüncenin geçtiği belirlenmiştir (Purdon and Clark, 2005). Beck (1976) tarafindan ortaya konan bilişsel terapi, çeşitli ruhsal bozukluklar için danışanı etkin kılan, yönlendirici ve yapılandırılmış bir yaklaşımı önerirken bu yapılandırmayı otomatik düşünce, şema ve inançlar gibi temel taşlar üzerine kurar (Arkar, 1993). Danışanların daha çok duygu, düşünce, istek ve tutumlar gibi içsel deneyimlerine vurgu yapan terapi modelinde (Tümkaya ve İflazoğlu, 2000) genel amaç, danışanın dış dünya ve kendisi ile ilgili algı ve değerlendirmelerini diğer bir ifadeyle psikolojik rahatsızlıkların temelini oluşturan mantık dışı şema, çıkarsama ve otomatik düşünce kalıplarının bireyler tarafından fark edilmesini sağlamaktır. Bunlardan olumlu/olumsuz otomatik benlik ifadeleri olarak da önerilen otomatik düşünceler, belli durumlarda bireyin kendi kendine söyledikleri ve tekrar eden düşüncelerini temsil etmektedir. Bu düşüncelerin en belirgin özel- 
liği de herhangi bir durumun aslını değil, bireyin o duruma ilişkin yaptığ yorumları içermesidir ve dolayısıyla bireyin duyguları ve buna bağlı ortaya çıkan davranışsal tepkileri, bu otomatik düşüncelere göre şekillenmektedir. Ani ve kendiliğinden bilinç dışı ortaya çıkan, diğer bir ifadeyle refleksif olarak nitelendirilebilecek bu düşünceler, birey tarafından üzerinde düşünülmeyen ve değerlendirilmeden doğruluğu kabul edilen düşünceler olma özelliği göstermektedirler (Beck, 2001). Yapılan bir çalışma, üniversite öğrencilerinin otomatik düşünceleri arttıkça zihinsel sağlık sorunlarının da arttığın göstermiştir (Calvete ve Connor-Smith, 2005).

Bireyce çarpitılmış olan bu değerlendirmeler; plansız, üzerinde düşünülmeden, sorgulanmadan ve otomatik olarak ortaya çıarken daha belirgin düşüncelerle birlikte bir akış içinde olma eğilimindedirler (Beck, 2001). Somut olan bu düşünceler; aynı zamanda belirli bir hedef ya da problem çözme gibi amaca yönelik mantıksal bir sıra izlemezken, nesnellikten uzak olmalarına rağmen meydana gelmeyi de sürdürürler (Haaga, Dyck ve Ernst, 1991). Bireyin kendisiyle ilgili içsel süreçlerini ve ifadelerini yansitan otomatik düşünceler, genel anlamda da bireyin dış dünya, gelecek ve kendisi hakkında olumsuz değerlendirme yapması ile (Gotlib, Coyne, 1983); aşırı genelleme, keyfi çıkarımlarla ön yargılarına neden olurken bu bakış açısıyla da psikolojik rahatsızlıkların temelini oluşturan düşünce kalıpları olarak görülürler (Davison ve Neale, 1998). Özetlersek Beck (1976), otomatik düşüncelerin özelliğini şöyle anlatmaktadır;

- Nettir ve biçimlenmiştirler.

- Özgüldür.

- Sürekliliği bulunmamaktadır.

- Telgraf tarzı ifade biçimi vardır.

- Amaç yönelimli düşünmede olduğu gibi veya sorun çözmede olduğu gibi mantıksal sıra izlemezler.

- Reflekslerde olduğu gibi birdenbire ortaya çıkarlar. (akt. Soygüt, 2003).

Olumsuz otomatik düşünceler olumsuz ve çarpık gerçeklik algısına yol açar ve bu yüzden olayların akıla bir biçimde değerlendirilmesini önler (Beck, 1979). Otomatik düşünceler çocukluktan beri geliştirilen içsel inanç kalıpları olan bilişsel şemaların yüzeye yakın şekli olarak ifade edilir. Beck (1995), otomatik düşüncelerin üç farklı şeklinin olabileceğini öngörmüştür: birincisi, halihazırda objektif kanıtlara ters düşen çarpıtılmış düşünceler, 
ikincisi doğru olabilen fakat bunlardan çıkarılan çarpıtılmış sonuçlar içeren düşünceler ve üu̧üncüsü ise doğru olan ama işlevsel olmayan düşünceler. Anlık ortaya çıkan ve bir değerlendirme içeren bu üç otomatik düşünce türünden en fazla kullanılanın birincisi olduğu düşünülmektedir (Murdock, 2016).

Yukarıda da değinildiği üzere Çözüm Odaklı Kısa Süreli Psikolojik Danışma Kuramı; bireyin kendi kaynaklarını kendini toparlama gücüne odaklayan, bireyi aktif kılan, onu amaçlı ve olumlu değişimin izinden gitmeye ve bunları nasıl kullanabileceğine dair cesaretlendiren bir yaklaşım olarak değerlendirilmektedir. Bilişsel yaklaşımda ise bireyin kendisiyle ilgili içsel süreçlerini yansıtan ve bireyin dış dünya, gelecek ve kendisi hakkında olumsuz değerlendirmeler yapmasına neden olan otomatik düşünceleri, psikolojik rahatsızlıkların temelini oluşturmaktadırlar. Bu bağlamda çözüm odaklı yaklaşım; öz düzenlemenin ön plana çıkarıldığı hedefe yönelim, bireyde var olan güçleri ve kaynakları kullanmayı içeren düşüncenin kaynaklarını harekete geçirme ve ortaya konan problemden dışsal bir ayrılma şeklinde görülen problemden ayırma süreci gibi alt boyutlara sahiptir. Bu özellikleri düşünüldüğünde bilişsel yaklaşımın vurguladığı, bireylerin belli durumlarda kendi kendilerine söyledikleri ve tekrarlayan düşüncelerini temsil eden otomatik düşüncelerle ilintili olduğu görülmektedir. Bu ilinti, çözüm odaklı yaklaşımın danışanı aktif kılması ve danışanın düşüncelerini sorun değil, çözüm odağında yönlendirmesi ile bu bağlamın otomatik düşüncelere etkisi araştırılmaya değer görülmektedir.

Christie, Tett, Cree, Hounsell ve McCune (2008) tarafından yapılan nitel bir çalışmada öğrencilerin üniversitedeki ilk yıllarında "kimliklerini yitirmiş" gibi hissettiklerini ifade ettikleri bulunmuştur. Üniversite yaşamı içerisinde öğrenciler zihinsel sağlık sorunlarına yol açabilecek zorlayıcı ve gelişimsel sorunlarla karşı karşıya gelebilmektedirler. Bu zorlayıcı ve gelişimsel sorunlarla karşı karşıya gelmek bireyin depresyon ve anksiyete yaşamasına sebep olabilmektedir. Bu durum ise bireylerin bilişsel yapısının bozulduğuna işaret eder ve olumsuz otomatik düşünceler bu bireylerde sıklıkla görülmektedir (Beck, 1976; Steer, Clark, Beck, Ranieri, 1995; Beck, Brown, Steer, Eidelson ve Riskind, 1987). Olumsuz otomatik düşüncelerin depresyona yol açttğı bilinmektedir. Son yıllarda üniversite öğrencilerinin yaklaşık üçte birinin depresif ve endişeli ruh hali belirtileri gösterdiği (Eisenberg, Gollust, Golberstein ve Hefner, 2007) ve dörtte birinin uyumsuz mükemmeliyetçi 
eğilimler sergilediği görülmektedir (Radhu ve ark., 2012). Üniversite eğitimi içinde olan öğrencilerin ruh sağlığı problemlerini önlemek için olumsuz otomatik düşüncelere önem vermenin gerekli olduğu görülmektedir. Öte yandan, mental sağlık problemleri olan üniversite öğrencilerinin bir çok olumsuz otomatik düşünceye sahip olduğu dikkate alındığında, bu öğrencilerin tedavisi için sahip oldukları olumsuz düşüncelerin giderilmesine odaklanmak gerekmektedir. Araştırmanın çalışma grubunun özellikleri incelendiğinde ise, $18-25$ yaş arası beliren yetişkinlik olarak tanımlanmış ve bu bireyler ne ergen ne de yetişkin olarak görülmüştür (Arnett, 2000). Beliren yetişkinlik döneminde, bireylerin yaşadığı değişkenlik, kendi başına hareket etme, kimlik sorgulaması, kararsızlık, olumsuzluk, yetişkinliğe adım atma dönemi olması ve bir çok farklı seçeneğin bulunması nedeniyle diğer gelişim dönemlerine kıyasla daha fazla stres ve olumsuz duygular yaşamaktadırlar (Schulenberg ve Zarrett 2005). Bu yaş aralığı bir çok genç için üniversite yıllarına denk gelmektedir. Beliren yetişkinlik içinde yer alan genç, kendini bazı zorlayıcı yaşantıların içinde bulur ve bu durum çözülmezse uzun vadede belki de önemli ruh sağllğı sorunlarına dönüş̧ebilir (Akın, 2009). Üniversite öğrencileri gündelik yaşamlarında birçok olumsuzluk ya da sorun ile karşı karşıya gelmektedirler. Beliren yetişkinlik içinde olan bu bireyler sorunlarını artık neredeyse tek başlarına çözmek durumunda kalırlar. Bu zorlayıc yaşantılar esnasında olumsuz otomatik düşüncelere başvurabilir, çözüm yollarını görmede başarısız başarısız kalabilirler. Bu noktada gençlerin karşılaştıkları sorunları çözmek için, çözüme odaklanma ve otomatik düşüncelerden uzaklaşmak için koruyucu ruh sağlığ hizmetlerinin verilmesi önem taşır. Koruyucu ruh sağlığı hizmetlerinin amacına hizmet edebilmesi ise yaşanan sorunları iyi tanımak ve önleyici çalışmalar yapmak gereklidir. Günümüzde, bireyin yaşadığı olumsuzluklarla nasıl baş ettiği ile ilgili ruh sağlı̆̆ı araştırmaları oldukça artmıştır (Hefferon ve Boniwell, 2011).

Çözüm odaklı kısa süreli psikolojik danışmanın hedefinde danışanın var olan potansiyelinin farkına varmasını sağlamak yer alır. Bilindiği üzere araştırmalar, farkındalık kazandırmanın bilişsel ve duygusal tepkileri düzenlemede olumlu katkıları olduğunu göstermektedir (Wiveka, Goldin, Carmona and McQuaid, 2004; Jain, Shapiro, Swanick, Roesch, Mills, Bell, and Schwartz 2007; Bowen, Witkiewitz, Dillworth and Marlattd, 2007). Böylece farkındalık kazanan bireylerin bilişsel yani düşüncelerini düzenlemeyi 
öğrenmeleri, onların çözüm odaklı olmalarına katkı sağlayacağına işaret edebilir. Koruyucu ve önleyici ruh sağllğ̆ hizmeti veren rehberlik ve psikolojik danışmanlık programında öğrenim gören bireylerle yapılan çalışmaların azlığı da bir o kadar dikkat çekicidir. Ayrıca bu program öğrencilerinin önce kendilerinin bir grup sürecinden geçmeleri ve farkındalık düzeylerinin artması, ardından diğer bireylere katkı sunmaları istenilen bir durumdur. Bu nedenle bu çalışmanın alanda bir boşluğu dolduracağı düşünülmektedir.

Tüm bu anlatılanlardan hareketle, araştırmacı tarafından hazırlanıp uygulanan çözüm odaklı kısa süreli grupla psikolojik danışma (ÇOKSPD) programıla katılımcların çözüm odaklı düşünme ve davranmayı hayata geçirmeleri ve otomatik düşüncelerinde azalmayı sağlamak hedeflenmiştir. Araştırmanın denenceleri;

1. Çözüm odaklı kısa süreli grupla psikolojik danışma programına katılan deney grubundakilerin, kontrol ve plasebo grubundakilere göre Çözüm Odaklı Envanter puanlarında (toplam) ve alt ölçek (problemden ayırma-hedefe yönelim-kaynakları harekete geçirme) puanlarında istatistiksel olarak anlamlı düzeyde bir artma olacaktır. Otomatik düşünceler ölçeğinde ise anlamlı düzeyde bir azalma olacaktır. Bu durum uygulamanın bitiminden 4 ay sonra yapılacak izleme ölçümlerinde kendini gösterecektir

2. Çözüm odaklı kısa süreli psikolojik danışma programına katılan deney grubundakilerin kontrol ve plasebo grubundakilere göre ÇOEproblemden ayırma alt ölçeği öntest-sontest puanları arasında son test lehine ve sontest-izleme puanları arasında ise izleme testi lehine anlamlı bir fark olacaktır.

3. Çözüm odaklı kısa süreli psikolojik danışma programına katılan deney grubundakilerin kontrol ve plasebo grubundakilere göre ÇOEhedefe yönelim alt ölçeği öntest-sontest puanları arasında son test lehine ve sontest-izleme puanları arasında ise izleme testi lehine anlamlı bir fark olacaktır.

4. Çözüm odaklı kısa süreli psikolojik danışma programına katılan deney grubundakilerin kontrol ve plasebo grubundakilere göre ÇOEkaynakları harekete geçirme alt ölçeği öntest-sontest puanları arasinda son test lehine ve sontest-izleme puanları arasında ise izleme testi lehine anlamlı bir fark olacaktır. 
5. Çözüm odaklı kısa süreli psikolojik danışma programına katılan deney grubundakilerin kontrol ve plasebo grubundakilere göre ÇOEtoplam öntest-sontest puanları arasinda son test lehine ve sontestizleme puanları arasında ise izleme testi lehine anlamlı bir fark olacaktır.

6. Çözüm odaklı kısa süreli psikolojik danışma programına katılan deney grubundakilerin kontrol ve plasebo grubundakilere göre otomatik düşünceler ölçeği öntest-sontest ve sontest-izleme testi puanları arasında son test lehine sontest-izleme puanları arasında ise izleme testi lehine anlamlı bir fark olacaktır.

\section{Yöntem}

Bu çalışmada, çözüm odaklı kısa süreli grupla psikolojik danışmanın, rehberlik ve psikolojik danışma lisans programı öğrencilerinin çözüm odaklı eğilimlerini geliştirmelerine ve otomatik düşüncelerini azaltmaya yönelik etkisini ortaya çıarmak amacına yönelik ön-son-izleme testi ile deney, kontrol ve plasebo gruplu yarı deneysel bir araştırmadır. Sosyal ve eğitim bilimlerinde yarı deneysel desen, deney ve kontrol gruplarının yansız (random) atama yoluyla oluşturulamaması durumlarında deneysel çalışmalardan ayrışır. Bazı yaşam deneyimlerine sahip, belirli yaşta ve cinsiyette katılımclarla araştırma yapmaya duyulan ihtiyaç yansız atama yapılmasını güçleştirmektedir (Bulduk, 2003). Bu çalışmada ön test-son test-izleme testi deney, kontrol ve plasebo grubu olan bir model kullanılmıştır. Deneysel çalışmalarda ön test ve son test kontrol gruplu deneysel desen çoğunlukla kullanılmaktadır. Katılımclar deneysel işlem öncesi ve deneysel işlem sonrası bağımlı değişkenlere göre ölçülürler (Büyüköztürk, 2007: 19).

\section{Verilerin Analizi}

Araştırma verilerinin istatistiksel çözümlemeleri için, çözüm odaklı kısa süreli grupla psikolojik danışma programına (ÇOKSPD) katılan deney grubu, hiçbir işlem yapılmayan kontrol grubu ve plasebo grubunu oluşturan deneklerin sayısının 10 olması nedeniyle nonparametrik teknikler kullanılmıştır. Deney ve kontrol grubundaki katılımcların otomatik düşünceler ölçeği ve çözüm odaklı envanter ön-son-izleme ölçümlerinden elde edilen 
puanlarını karşılaştırmak için Wilcoxon İşaretli Sıralar testi ve Mann Whitney-U testi kullanılmıştır. Veriler SPSS 18 bilgisayar programında çözümlenmiştir.

\section{Araştırmanin deseni}

Çözüm odaklı kısa süreli grupla psikolojik danışma (ÇOKSPD) programı hazırlanarak, RPD lisans öğrencilerinin çözüm odaklı eğilimleri ve otomatik düşünceleri üzerindeki etkisini ölçmek amaciyla, deney-kontrol-plasebo grupları ile ön-son-izleme testleri uygulanan yarı deneysel bir araştırma hazırlanmıştır. Araştırmada ön test-son test-izleme testi kontrol ve plasebo gruplu model kullanılmıştır. Böyle bir modelde deneysel işlem öncesi ve deneysel işlem sonrası katılımcıların bağımlı değişkenle ilgili olarak ölçümleri yapılır (Büyüköztürk, 2007: 19). Deneysel uygulama sonucunda, "Çözüm Odaklı Kısa Süreli Psikolojik Danışma (ÇOKSPD)” programında yer alan grupta meydana gelecek değişmenin uygulanan programdan kaynaklandığını belirleyebilmek amacı ile kontrol grubu kullanılmıştır. Bu çalışmasının bağımsız değişkeni çözüm odaklı kısa süreli grupla psikolojik danışma programıdır. Araştırmanın bağımlı değişkeni ise otomatik düşünceler ve çözüm odaklı eğilimlerdir.

\section{Çalışma grubu}

Araştırmanın deney, kontrol ve plasebo grupların belirlemek amacıyla "Kişisel Bilgi Formu" ve araştırmanın bağımlı değişkenlerini ölçmek için "Çözüm Odaklı Envanter" ve "Otomatik Düşünceler Ölçeği” kullanılmıştır. Bu araştırmanın katılımcların 2018-2019 eğitim-öğretim yılı Aksaray Üniversitesi Eğitim Fakültesi-RPD ana bilim dalına devam eden öğrenciler oluşturmaktadır. Ölçekler 2018-2019 eğitim-öğretim yılında Rehberlik ve Psikolojik Danışma (RPD) lisans programında öğrenim gören ve gönüllü olan 78 (\%75.7) kız, 25 (\%24.3) erkek, toplam 103 öğrenciye araştırmacı tarafından uygulanmıştır. RPD lisans programlarında genellikle öğrenim gören kız öğrenci sayısının erkek öğrenci sayısından daha çok olduğu görülmektedir. Deney, kontrol ve plasebo gruplarınin belirlenmesinde bu durum dikkate alınmıştır. Deney grubunda yer alacak katılımcları belirlemek için öğrencilerin programa katılmaya istekli olup olmadıkları sorulmuş ve katılmak 
isteyenler arasından deney grubu oluşturulmuştur. Çözüm Odaklı Envanterinden ve otomatik düşünceler ölçeğinden alınan puanlara göre çalışmaya katılmaları uygun olan 35 öğrenci belirlenmiştir. Ardından çalışmalara katılmaya gönüllü olan ve ayrıca zamanı uygun olanlar arasından $6 \mathrm{kız} 4 \mathrm{er}-$ kek toplam 10 öğrenci belirlenmiştir. Deney grubu 10 (6 kız, \% 60.0; 4 erkek, $\%$ 40.0), kontrol grubu (7 kız, \% 70.0; 3 erkek, \% 30.0) ve plasebo grubu (7 kız, \% 70.0; 3 erkek, \% 30.0) toplam 10'ar öğrenciden oluşmuştur. Öğrencilerin yaşları 20-25 arasında olup yaş ortalaması 21'dir. Öğrenciler ailelerinin maddi gelir seviyesinin orta düzeyde olduğunu ifade etmişlerdir. Çözüm Odaklı Kısa Süreli Psikolojik Danışma (ÇOKSPD) programının başlamasından bir hafta önce deney, kontrol ve plasebo gruplarıly bir araya gelinmiştir. Bu buluşmada, deney ve plasebo gruplarına programın işleyişi ve süreci hakkında bilgi verilmiştir. Kontrol grubundaki öğrencilere ise hiçbir şey söylenmemiştir.

\section{Veri toplama araçlar}

$\mathrm{Bu}$ araştırmada ilk olarak öğrencilerin demografik özellikleri için "Kişisel Bilgi Formu" kullanılmıştır. Formda öğrencilerin yaşı, cinsiyeti, sosyoekonomik durumlarına cevap aranmıştır. Bağımlı değişkenleri ölçmek için Çözüm Odaklı Envanter ve Otomatik Düşünceler Ölçekleri kullanılmıştır.

Çözüm Odaklı Envanter (ÇOE): Grant, Cavanagh, Kleitman, Spence, Lakota ve Yu (2012) tarafından geliştirilen ölçek, Karahan ve Hamarta (2015) tarafından Türkçe'ye çevrilmiştir. Ölçek, bireyin çözüm odaklı düşünmeye yönelik eğilim gösterip göstermediğini ölçmeyi hedefler. AMOS ve SPSS 16.00 programlarıyla ÇOE'in geçerlilik ve güvenirlik analizleri yapılmıştır. Dil eşdeğerliğini sağlamak amacıyla yapılan analizlerden elde edilen sonuçlara göre Türkçe ve esas formdaki puanlar arasındaki korelasyonlar; Problemden Ayırma alt ölçeği için .92, Hedefe Yönelim alt ölçeği için .94, Kaynaklarn Harekete Geçirme alt ölçeği için 91 olarak bulunmuştur. Test-tekrar test güvenirliği için 16 hafta sonra yapılan ölçümlerde .84 bulunmuştur. Cronbach alfa değeri 84 bulunmuştur. Ölçeğin yapı geçerliği için ölçüt bağıntılı geçerlik hesaplaması yapılmıştır. Farklı bir örneklem grubundan elde edilen 66 erkek 137 kız olmak üzere toplam 197 üniversite öğrencisi üzerinde yapılan hesaplamalarda, Yaşam Doyumu Ölçeği ile yapılan ölçüt 
bağıntılı geçerlilik çalışmasında Cronbach alfa değeri .86 bulunmuştur. Psikolojik İyi Oluş Ölçeği ile yapılan araştırmada ise, Cronbach alfa değeri .85 olarak bulunmuştur. Depresyon Anksiyete Stres Ölçeği-21 ile yapılan araştırmada ise, Croanbach alfa değeri .89 olarak bulunmuştur. Uyum indeksi değerleri ise, RMSEA $=.072 \mathrm{CFI}=.94, \mathrm{IFI}=.94, \mathrm{TLI}=.91, \mathrm{GFI}=.93, \mathrm{AGFI}=.87$ olarak hesaplanmıştır. Uyum indeksi değerleri incelendiğinde modelin iyi uyum verdiği görülmektedir. Açımlayıcı (AFA) ve doğrulayıcı faktör analizi (DFA) ile Çözüm Odaklı Envanterin yapı geçerliği bulunmuştur. Çözüm Odaklı Envanter'in güverliliği için iç tutarlık yöntemi kullanılmıştır. Açımlayıcı Faktör Analizi ile yapı geçerliği incelenmiş; 12 maddeden oluşan ve toplam varyansın \% 61'ini açıklayan üç faktörlü bir yapının ortaya çıtığ1 görülmüştür. Faktörler altında yer alan maddelerin hepsi özgün formdaki faktörlere uygun bir dağılım sergilemiştir. 3 faktörden oluşan ve 12 madde olan yapıda maddelerin faktör yüklerinin .50'ın üzerinde olduğu görülmüş ve analiz sonunda envanterden madde çıkarılmamıştır. Ayrıca DFA için uyum indeksi sınırları dikkate alınarak modelin iyi bir seviyede uyum gösterdiği ayrıca envanterin esas faktör yapısının Türkçe versiyonunun faktör yapısıyla uyum gösterdiği bulunmuştur. Yapı geçerliliği için örneklemden elde edilen iç tutarlık "problemden ayırma" alt ölçeği için .77 olarak hesaplanmıştır. Ardından "hedefe yönelim" için .84 olarak hesaplanmış ve "kaynakları harekete geçirme" alt ölçeği için ise .70 olarak hesaplanmıştır. Geçerlilik sonuçları incelendiğinde envanterin özgün hali ile Türkçe sürümü arasında bulguların benzer değerlerde olduğu hesaplanmıştır. Envanterin güvenirlik çalışmaları devam etmektedir (Grant vd., 2012; Grant, 2011; Karahan ve Hamarta, 2015). Bu çalışma kapsamında ise 125 öğrenciye ölçme aracı uygulanmış SPSS 18 paket programı 119 kişinin puanlarını dikkate almış ve iç tutarlılık katsayısı "genel toplam puan" için .79, "problemden ayırma" için .68, "hedefe yönelim" için .80 ve "kaynakları harekete geçirme" alt boyutları için .69 olarak bulunmuştur. Çözüm odaklı envanter bireyin kendisinin doldurduğu bir kağıt-kalem ölçeği olup 12 maddeden oluşmaktadır. Ölçek 6'lı Likert tipinde olup, kesinlikle katılmıyorum=1'den başlayarak, kesinlikle katılıyorum=6'ya doğru değişen aralıktadır. Çözüm odaklı envanterin alt boyutlarının maddeleri şöyledir; 1 . Problemden ayırma 1, 2, 4, 5, 2. Hedefe yönelim 9, 10, 11, 12, 3. Kaynakları harekete geçirme 3, 6, 7 ve 8 dir. Ölçeğin 1., 2., 4. ve 5. maddeleri ise tersten puanlanmaktadır. Ölçek alt boyutları ayrı ayrı hesaplanacağı gibi toplam puanı da alınabilen bir ölçek- 
tir. Envanterden en az puan 12, en çok ise 72 puan alınabilmektedir. Puanın yüksek olması bireyin çözüm odaklı düşünmeye doğru değişiminin arttığını göstermektedir.

Otomatik Düşünceler Ölçeği (ODÖ): depresyonla ilişkili olumsuz otomatik düşüncelerin ortaya çıkma olasılığını ölçen ODÖ, S.D. Hollon ve P. C. Kendall (1980) tarafından geliştirilmiş, Türkçe'ye 1990'da G. Aydın ve O. Aydın ile 1992 ' de N. H. Şahin ve N. Şahin tarafından uyarlanmıştır. Ölçek bir bireyin, kendine yönelik olumsuz değerlendirmeleri ne sıklıkta kullandığını ölçmeyi amaçlamaktadır. Ölçek, 30 maddeden oluşmaktadır ve 1-5 arasında puanlanan 5'li Likert tipi bir ölçme aracıdır. Ölçme aracının ters puanlanan maddesi ve alt boyutları bulunmamaktadır. Ölçekten en yüksek 150, en düşük 30 puan alınabilmektedir. Ölçekten yüksek puan almak, kişinin olumsuz otomatik düşüncelerinin sıklığın, bu düşüncelerin fazlaca ortaya çıktığını göstermektedir. Ölçeğin orijinal formunun uygulaması 788 üniversite öğrenci ile gerçekleştirilmiştir. Güvenirlik katsayısı için üç ayrı gruba ölçek uygulanmış ve $.94, .89$ ve .91 cronbach alfa iç güvenirlik katsayısı elde edilmişitir. Yarıya bölme güvenirliği için ise .91 , .59 ve .87 değerleri elde edilmiştir. Ölçeğin geçerliği için ölçüt bağıntılı geçerlik kullanılmış Beck Depresyon Envanteri ile korelasyonu .87, MMPI-D ile korelasyonu .85 olarak bulunmuştur. Türkiye'de Şahin ve Şahin (1992) tarafından 0.93, Aydın ve Aydın (1990) tarafından da 95 olarak güvenirlik çalışmalarında Cronbach Alfa iç tutarlılık değeri hesaplanmıştır. Şahin ve Şahin (1992) tarafından 91 yarıya bölme güvenirliği bulunmuştur. Aydın ve Aydın (1990) ise test tekrar test güvenirliğini .77 olarak hesaplamıştır. Ölçüt bağıntılı geçerlik çalışması yapılmış ve Şahin ve Şahin (1992), Beck Depresyon Envanteri ile korelasyonunu .75, Aydın ve Aydın (1990), MMPI-D ile .85 bulmuştur. Şahin ve Şahin (1992) ölçeğin her bir maddesinin ayrı ayrı geçerliğine bakmış ve 30 maddenin tamamının ayırıcı geçerliği olduğunu bulmuştur.

\section{Deneysel uygulama}

Araştırmacı tarafından hazırlanan "çözüm odaklı kısa süreli grupla psikolojik danışma (ÇOKSPD)" programı çözüm odaklı terapi kuramı temelinde hazırlanmış bir programdır. Her oturum 60-90 dakika olarak toplam 6 oturum şeklinde planlanmıştır. Program, katılımciların duygu, düşünce ve 
davranışlarına yönelik farkındalık kazanmalarını sağlama, ilk oturumda belirledikleri davranışsal amaçlarına ulaşmalarını sağlama, değişim ve gelişimlerini arttırmaya yönelik çalışmalar yaparak amaçlarına ulaşılmalarını sağlama şekilde hazırlanmıştır. Plasebo grubuyla ise eğitimlerindeki eksiklikler, istekleri, ihtiyaçları hakkında konuşulmuş katılımcıların önerileri ve yorumları dinlenmiştir. Oturumlar yaklaşık 60 dakika kadar sürmüş ve 6 oturumdan oluşmuştur. Kontrol grubu ile herhangi bir çalışma yapılmamıştır. Araştırmacının hazırladığı programın içeriği şöyledir;

1. Hafta: tanışma, uyum ve güvenin oluşmasının sağlanması, davranışsal amaçların belirlenmesi. Ödev olarak amaçları üzerinde bir hafta boyunca düşünmelerinin istenmesi.

2. Hafta: davranışsal amaçların gözden geçirilmesi (belirlememiş olanlar için bu oturum içinde belirlemelerinin istenmesi). Davranışsal amaçları$\mathrm{n}$ değiştirmek isteyenlerin olması durumunda yeniden amaç belirlenmesi. Derecelendirme skalanın kullanılarak katılımcılara amaçları ile ilgili şimdiki durumları ve gelecekte ne istediklerinin ortaya çıarılması.

3. Hafta: katılımcıların amaçlarıyla ilgili istisna durumlarının ortaya çıkarılması. Mucize sorunun sorulması. Verilen yanttlara göre ödevlerinin verilmesi.

4. Hafta: mucize soru ve ödevlerinin üzerinden geçilmesi. Döngüsel soruların sorulması ve cevapların dinlenilmesi. Skaladaki değişim için ödevlerin tekrarlanması ve/veya güncellenmesi.

5. Hafta: skaladaki değişimin sağlanması için yapılan ödevler gösterilen çaba için amigoluk yapmak ve katılımclara mesaj yazmak.

6. Hafta: davranışsal amaçlarına ulaşıp ulaşmadıklarının sorgulanması, sonlandırma yapmak.

Deney, kontrol ve plasebo gruplarının çözüm odaklı envanter toplam puanları ve alt ölçek puanları (probleme odaklanma, hedefe yönelim, kaynakları harekete geçirme) ve otomatik düşünceler için deneysel çalışmaya başlamadan önce aralarındaki farklılıkları ortaya çıkarmak amacıyla Mann Whitney-U testi yapılmıştır. Deney, kontrol ve plasebo grupları çözüm odaklı envanterinin;

1. Probleme odaklanma alt boyutu arasında deney ve kontrol grupları için $\left(\mathrm{U}=22.500, \mathrm{z}=0.35, \mathrm{p}<.05, \quad\right.$ Ort. $\pm \mathrm{Ss}_{\text {(deney })}=16.50 \pm 3.71, \quad$ Ort. $\pm \mathrm{Ss}$ (kontrol) $=$ 13.60 \pm 1.71$)$ anlamlı bir fark olduğu görülmektedir. Probleme odaklan- 
ma alt boyutu arasında deney ve plasebo grupları için (U=39.500, $\mathrm{z}=$. $315, \mathrm{p}>.05$, Ort. $\pm \mathrm{Ss}_{\text {(deney) }}=16.50 \pm 23.71$, Ort. $\pm S \mathrm{~s}$ (plasebo) $=17.30 \pm 2.62$ ) anlaml bir fark olmadığ 1 görülmektedir. Probleme odaklanma alt boyutu arasinda kontrol ve plasebo grupları için $(\mathrm{U}=12.500, \mathrm{z}=.003 \mathrm{p}>.05$,

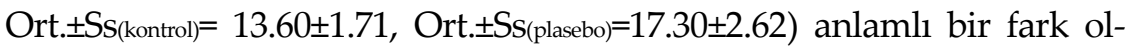
duğu görülmektedir.

2. Hedefe yönelim alt boyutu deney ve kontrol grupları için $(\mathrm{U}=36.500, \mathrm{z}=$ .315 , p $>.05$, Ort. $\pm S s_{(\text {deney })}=16.70 \pm 2.83$, Ort. $\left.\pm S s_{(\text {kontrol })}=15.30 \pm 3.02\right)$ anlaml bir fark olmadığ 1 görülmektedir. Hedefe yönelim alt boyutu deney ve plasebo grupları için $(\mathrm{U}=35.000, \mathrm{z}=.280, \mathrm{p}>.05$, Ort. $\pm S \mathrm{~S}$ (deney) $=16.70 \pm 2.83$, Ort. $\pm S s$ (plasebo) $=14.80 \pm 1.87)$ anlamlı bir fark olmadığ görülmektedir. Hedefe yönelim alt boyutu kontrol ve plasebo grupları için $(\mathrm{U}=40.000, \mathrm{z}=$ $.481, \mathrm{p}>.05$, Ort. $\pm \mathrm{Ss}_{(\text {kontrol })}=15.30 \pm 3.02$, Ort. $\pm S \mathrm{~s}($ plasebo $)=14.80 \pm 1.87$ ) anlaml bir fark olmadığı görülmektedir.

3. Kaynakları harekete geçirme alt boyutu deney ve kontrol grupları için $\left(\mathrm{U}=48.500, \mathrm{z}=.912, \mathrm{p}>.05\right.$, Ort. $\pm \mathrm{Ss}($ deney $)=17.50 \pm 1.50, \quad$ Ort. $\pm S s_{(\text {kontrol })}=$

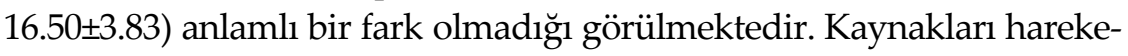
te geçirme alt boyutu deney ve plasebo grupları için $(\mathrm{U}=42.500, \mathrm{z}=.579$, $\mathrm{p}>.05$, Ort. $\pm S \mathrm{~s}_{\text {(deney) }}=17.50 \pm 1.50$, Ort. $\pm S \mathrm{~S}$ (plasebo) $=17.80 \pm 1.87$ ) anlamlı bir fark olmadığı görülmektedir. Kaynakları harekete geçirme alt boyutu kontrol ve plasebo grupları için $(\mathrm{U}=43.000, \mathrm{z}=.631, \mathrm{p}>.05$, Ort.. $\mathrm{Ss}$ (kontrol) $=$ $16.50 \pm 3.83$, Ort. $\pm S s$ (plasebo) $=17.80 \pm 1.87$ ) anlamlı bir fark olmadığ 1 görülmektedir.

4. Genel toplamının deney ve kontrol grupları için $(\mathrm{U}=23.500, \mathrm{z}=.05$, $\mathrm{p}>.05$, Ort. \pm Ss (deney) $=50.70 \pm 4.59$, Ort. \pm Ss(kontrol) $=45.40 \pm 7.13$ ) anlamlı bir fark olmadığı görülmektedir. Genel toplamının deney ve plasebo grupları için $(\mathrm{U}=44.000, \mathrm{z}=.684, \mathrm{p}>.05, \quad$ Ort.. $\mathrm{Ss}$ (deney) $=\quad 50.70 \pm 4.59$, Ort. $\pm S$ s(plasebo) $=60.40 \pm 13.25$ ) anlamlı bir fark olmadığı görülmektedir. Genel toplamının kontrol ve plasebo grupları için $(\mathrm{U}=27.500, \mathrm{z}=.089$, $\mathrm{p}>.05$, Ort. $\pm \mathrm{Ss}($ kontrol $)=45.40 \pm 7.13$, Ort. \pm Ss(plasebo $)=60.40 \pm 13.25)$ anlamlı bir fark olmadığı görülmektedir.

ÇOE-öntest puanlarında sadece probleme odaklanma alt boyutunda deney-kontrol ve kontrol-plasebo arasında istatistiksel olarak anlamlı bir fark görülmüştür. Diğer alt boyutlarda ise anlamlı bir fark olmadığı bulunmuş- 
tur. Bağımlı değişken bakımından grupların deneysel çalışmaya başlamadan önce birbirine denk olduğu söylenebilir.

Mann Whitney-U testi sonuçlarına göre; deney, kontrol ve plasebo grupları otomatik düşünceler ölçeği öntest puanları arasında, deney ve kontrol grupları için $(\mathrm{U}=36.500, \quad \mathrm{z}=.315 \quad \mathrm{p}>.05, \quad$ Ort. $\pm S \mathrm{~s}$ (deney) $=69.90 \pm 26.52$, Ort. $\pm S s($ kontrol $)=68.30 \pm 15.17)$, Deney ve plasebo grupları için $(\mathrm{U}=48.000, \mathrm{z}=.912$ $\mathrm{p}>.05$, Ort. $\pm S \mathrm{~S}$ (deney) $=69.90 \pm 26.52$, Ort. $\left.\pm S S_{\text {(plasebo) }}=60.40 \pm 13.25\right)$. Kontrol ve plasebo grupları için $(\mathrm{U}=34.000, \mathrm{z}=.247 \mathrm{p}>.05$, Ort. $\pm \mathrm{Ss}$ (kontrol) $=68.30 \pm 15.17$, Ort. \pm Ss(plasebo) $=60.40 \pm 13.25$ ) istatistiksel olarak anlamlı bir fark olmadığı bulunmuştur. Bağımlı değişkenlere göre grupların deneysel çalışmaya başlamadan önce birbirine denk olduğu söylenebilir.

\section{Bulgular}

Deney, kontrol ve plasebo grubundaki katılımcların deney öncesinden sonrasına ve izleme ölçümlerinde çözüm odaklı eğilimlerinin ve otomatik düşüncelerinin aritmetik ortalama ve standart sapma değerleri aşağıdaki Tablo 1'de gösterilmiştir.

Tablo 1. Deney, kontrol ve plasebo gruplarnin öntest-sontest ve izleme testinden aldiklan puanlarn aritmetik ortalama ve standart sapma değerleri

\begin{tabular}{|c|c|c|c|c|c|c|c|c|c|c|c|}
\hline Deney & n & $\bar{X}$ & sd & Kontrol & $\mathbf{n}$ & $\bar{X}$ & sd & Plasebo & $\mathbf{n}$ & $\bar{X}$ & sd \\
\hline Ön proayr & 10 & 16.50 & 3.71 & $\begin{array}{l}\text { Ön } \\
\text { proayr }\end{array}$ & 10 & 13.60 & 1.71 & $\begin{array}{l}\text { Ön } \\
\text { proayr }\end{array}$ & 10 & 17.30 & 2.62 \\
\hline Ön hedyönm & 10 & 16.70 & 2.83 & $\begin{array}{l}\text { Ön } \\
\text { hedyönm }\end{array}$ & 10 & 15.30 & 3.02 & $\begin{array}{l}\text { Ön } \\
\text { hedyönm }\end{array}$ & 10 & 14.80 & 1.87 \\
\hline $\begin{array}{l}\text { Ön } \\
\text { kayhgec }\end{array}$ & 10 & 17.50 & 1.50 & $\begin{array}{l}\text { Ön } \\
\text { kayhgec }\end{array}$ & 10 & 16.50 & 3.83 & $\begin{array}{l}\text { Ön } \\
\text { kayhgec }\end{array}$ & 10 & 17.80 & 1.87 \\
\hline $\begin{array}{l}\text { Ön } \\
\text { coeTop }\end{array}$ & 10 & 50.70 & 4.59 & $\begin{array}{l}\text { Ön } \\
\text { coeTop }\end{array}$ & 10 & 45.40 & 7.13 & $\begin{array}{l}\text { Ön } \\
\text { coeTop }\end{array}$ & 10 & 60.40 & 13.25 \\
\hline Son proayma & 10 & 19.50 & 1.84 & $\begin{array}{l}\text { Son } \\
\text { proayma }\end{array}$ & 10 & 15.60 & 2.54 & $\begin{array}{l}\text { Son } \\
\text { proayma }\end{array}$ & 10 & 14.40 & 2.06 \\
\hline Son hedyön & 10 & 19.40 & 1.64 & $\begin{array}{l}\text { Son } \\
\text { hedyön }\end{array}$ & 10 & 16.60 & 3.65 & $\begin{array}{l}\text { Son } \\
\text { hedyön }\end{array}$ & 10 & 14.00 & 1.69 \\
\hline $\begin{array}{l}\text { Son } \\
\text { kayhgec }\end{array}$ & 10 & 20.00 & 2.26 & $\begin{array}{l}\text { Son } \\
\text { kayhgec }\end{array}$ & 10 & 19.10 & 1.85 & $\begin{array}{l}\text { Son } \\
\text { kayhgec }\end{array}$ & 10 & 14.80 & 1.68 \\
\hline $\begin{array}{l}\text { Son } \\
\text { coeTop }\end{array}$ & 10 & 58.90 & 4.48 & $\begin{array}{l}\text { Soncoe- } \\
\text { Top }\end{array}$ & 10 & 51.30 & 5.35 & $\begin{array}{l}\text { Son } \\
\text { coeTop }\end{array}$ & 10 & 43.20 & 2.20 \\
\hline İzprodklnma & 10 & 15.00 & 2.44 & $\begin{array}{l}\text { İzprod- } \\
\text { klnma }\end{array}$ & 10 & 12.70 & 4.11 & $\begin{array}{l}\text { İzprod- } \\
\text { klnma }\end{array}$ & 10 & 17.10 & 4.28 \\
\hline İzhedyönlim & 10 & 13.70 & 1.49 & $\begin{array}{l}\text { İzhedyönl } \\
\text { im }\end{array}$ & 10 & 17.10 & 3.07 & $\begin{array}{l}\text { İzhedyönli } \\
\mathrm{m}\end{array}$ & 10 & 16.90 & 2.23 \\
\hline
\end{tabular}




\begin{tabular}{lccclccccccc}
\hline İzkaharkgec & 10 & 13.70 & 1.49 & $\begin{array}{l}\text { İzkahark- } \\
\text { gec }\end{array}$ & 10 & 17.70 & 3.23 & $\begin{array}{l}\text { İzkahark- } \\
\text { gec }\end{array}$ & 10 & 17.30 & 2.55 \\
\hline İzcoetop & 10 & 42.40 & 3.74 & İzcoetop & 10 & 47.50 & 4.74 & İzcoetop & 10 & 51.30 & 6.89 \\
\hline Önotomdüş & 10 & 69.90 & 26.52 & $\begin{array}{l}\text { Önotom- } \\
\text { düş }\end{array}$ & 10 & 68.30 & 19.17 & $\begin{array}{l}\text { Ön } \\
\text { otomdüş }\end{array}$ & 10 & 60.40 & 13.25 \\
\hline $\begin{array}{l}\text { Son } \\
\text { otomdüş }\end{array}$ & 10 & 52.80 & 15.68 & $\begin{array}{l}\text { Son } \\
\text { otomdüş }\end{array}$ & 10 & 60.00 & 14.36 & $\begin{array}{l}\text { Son } \\
\text { otomdüş }\end{array}$ & 10 & 89.60 & 4.16 \\
\hline $\begin{array}{l}\text { İzotomdüş } \\
\text { I0 }\end{array}$ & 53.90 & 15.18 & $\begin{array}{l}\text { İzotom- } \\
\text { düş }\end{array}$ & 10 & 68.00 & 21.48 & İzotomdüş & 10 & 61.60 & 16.16 \\
\hline
\end{tabular}

Deney, kontrol ve plasebo grubundaki katılımcların deney öncesinden sonrasına ve izleme ölçümlerinde çözüm odaklı eğilimlerinin ve otomatik düşüncelerinin anlamlı farklılık gösterip göstermediğine ilişkin KruskalWallis H Testi ve ortalamalar arasında gözlenen farkın istatistiksel olarak anlamlı olup olmadığı Mann Whitney-U testi sonuçları aşağıda Tablo 2, Tablo 3, Tablo 4 ve Tablo 5'de gösterilmiştir.

Çözüm Odaklı Envanter (ÇOE) Toplam Puanlarn ve Alt Ölçekleri ile Otomatik Düşünceler Ölçeğine İlişkin Kruskal-Wallis H ve Mann-Whitney U Testi Bulgularn

Araştırmanın 1. denencesi "Çözüm odaklı kısa süreli grupla psikolojik danışma programına katılan deney grubundakilerin, kontrol ve plasebo grubundakilere göre Çözüm Odaklı Envanter puanlarında (toplam) ve alt ölçek (problemden ayırma-hedefe yönelim-kaynakları harekete geçirme) puanlarında istatistiksel olarak anlamlı düzeyde bir artma olacaktır. Otomatik düşünceler ölçeğinde ise anlamlı düzeyde bir azalma olacaktır. Bu durum programın bitiminden 4 ay sonra yapılacak izleme ölçümlerinde kendini gösterecektir." şeklinde ifade edilmişti.

Deney grubu ile plasebo ve kontrol grubundaki öğrencilerin ÇOEproblemden ayırma, hedefe yönelim, kaynakları harekete geçirme ve otomatik düşünceler ölçeğinden aldıkları son ölçüm ve izleme ölçümü puanlarının ortalamaları arasında gözlenen farkın istatistiksel olarak anlamlı olup olmadığ 1 Kruskal-Wallis $\mathrm{H}$ testi incelenmiş elde edilen sonuçlara ilişkin bulgular Tablo 2'de verilmiştir. 
Tablo 2. Deney, Kontrol Ve Plasebo Gruplarndaki Öğrencilerin Çözüm Odaklı Envanteri Toplam Puanlan ile Problemden Ayırma-Hedefe Yönelim-Kaynaklan Harekete Geçirme Alt Boyutlarn ve Otomatik Düşünceler Ölçeği Sontest ve İzleme Testi Puanlarna Uygulanan Kruskal-Wallis H Testi Sonuçlarn

\begin{tabular}{|c|c|c|c|c|c|c|}
\hline Ölçümler & Grupar & $\mathbf{n}$ & $\begin{array}{l}\text { Sira } \\
\text { ortalamas1 }\end{array}$ & Sd & $\mathbf{X}^{2}$ & $\mathrm{p}$ \\
\hline Sontest & Deney & 10 & 23.95 & 2 & 14.935 & $.001^{*}$ \\
\hline ÇOE- & Kontrol & 10 & 9.50 & & & \\
\hline Problem Ayrm. & Plasebo & 10 & 13.50 & & & \\
\hline İzleme & Deney & 10 & 15.15 & 2 & 5.587 & 061 \\
\hline ÇOE- & Kontrol & 10 & 20.30 & & & \\
\hline Problem Ayrm. & Plasebo & 10 & 11.05 & & & \\
\hline Sontest & Deney & 10 & 23.00 & 2 & 14.855 & $.001^{*}$ \\
\hline ÇOE- & Kontrol & 10 & 7.95 & & & \\
\hline Hed.Yönl. & Plasebo & 10 & 15.50 & & & \\
\hline İzleme & Deney & 10 & 7.85 & 2 & 11.545 & $003^{*}$ \\
\hline ÇOE- & Kontrol & 10 & 19.50 & & & \\
\hline Hed.Yönl. & Plasebo & 10 & 19.15 & & & \\
\hline Sontest & Deney & 10 & 21.35 & 2 & 16.995 & $.000^{*}$ \\
\hline ÇOE- & Kontrol & 10 & 6.30 & & & \\
\hline Kayn.Hr.Geç. & Plasebo & 10 & 18.85 & & & \\
\hline İzleme & Deney & 10 & 8.00 & 2 & 11.038 & $004^{*}$ \\
\hline ÇOE- & Kontrol & 10 & 19.20 & & & \\
\hline Kayn.Hr.Geç. & Plasebo & 10 & 19.30 & & & \\
\hline Sontest & Deney & 10 & 24.45 & 2 & 20.426 & $.000^{*}$ \\
\hline ÇOE- & Kontrol & 10 & 6.70 & & & \\
\hline Toplam & Plasebo & 10 & 15.30 & & & \\
\hline İzleme & Deney & 10 & 8.65 & 2 & 10.158 & $.006^{*}$ \\
\hline ÇOE- & Kontrol & 10 & 20.90 & & & \\
\hline Toplam & Plasebo & 10 & 16.95 & & & \\
\hline Sontest & Deney & 10 & 9.50 & 2 & 18.922 & $.000^{*}$ \\
\hline \multirow[t]{2}{*}{ Otom.Düşn. } & Kontrol & 10 & 25.30 & & & \\
\hline & Plasebo & 10 & 11.70 & & & \\
\hline İzleme & Deney & 10 & 12.45 & 2 & 1.977 & .372 \\
\hline \multirow[t]{2}{*}{ Otom.Düşn. } & Kontrol & 10 & 17.85 & & & \\
\hline & Plasebo & 10 & 16.20 & & & \\
\hline
\end{tabular}

Tablo 2'de görüldüğü gibi, Kruskal-Wallis H testi sonuçlarına göre; deney, kontrol ve plasebo grupları ÇOE-problemden ayırma $\left(\mathrm{X}^{2}=14.935, \mathrm{p}<\right.$ $0.05)$, hedefe yönelim $\left(X^{2}=14.855, p<0.05\right)$, kaynakları harekete geçirme $\left(X^{2}=\right.$ $16.995, p<0.05)$ ve toplam puanları $\left(X^{2}=20.426, p<0.05\right)$ ile otomatik düşünceler ölçeği $\left(X^{2}=18.922, p<0.05\right)$ son testi puanları arasında istatistiksel olarak anlamlı bir fark olduğu bulunmuştur. Bu bulgu, deney, kontrol ve plasebo grupları arasında ÇOE- ve alt ölçekleri ile otomatik düşünceler ölçeğinden alınan puanlarda farklı etkilere sahip olduğunu göstermektedir. 
ÇOE-problemden ayırma izleme ölçümlerinde $\left(X^{2}=5.587, p>0.05\right)$ istatistiksel olarak anlamlı bir fark çıkmamıştır. Bu durum deneysel çalışmanın etkilerinin devam ettiğini göstermektedir. ÇOE-Hedefe yönelim izleme ölçümlerinde $\left(X^{2}=11.545, \mathrm{p}<0.05\right)$ istatistiksel olarak anlamlı bir fark çımıştır. Çıkan farkın hangi gruplardan kaynakandığını bulmak için Mann-U yapılmış ve kontrol grubunun hedefe yönelim puanlarında artış olduğu bulunmuştur. ÇOE-kaynakları harekete geçirme izleme ölçümlerinde $\left(\mathrm{X}^{2}=\right.$ 11.038, $\mathrm{p}<0.05)$ istatistiksel olarak anlamlı bir fark çıkmıştır. Çıkan farkın hangi gruplardan kaynakandığını bulmak için Mann-U yapılmış ve plasebo grubunun kaynakları harekete geçirme puanlarında artış olduğu bulunmuştur. ÇOE-toplam puan izleme ölçümlerinde $\left(\mathrm{X}^{2}=10.158, \mathrm{p}<0.05\right)$ istatistiksel olarak anlamlı bir fark çıkmıştır. Çıkan farkın hangi gruplardan kaynakandığını bulmak için Mann-U yapılmış ve kontrol grubunun ÇOE toplam puanlarında düşüş olduğu bulunmuştur. Otomatik düşünceler ölçeğinin izleme ölçümlerinden alınan verilere göre $\left(X^{2}=1.977, p>0.05\right)$ istatistiksel olarak anlamlı bir fark çıkmamıştır. Ayrıca deney grubundaki düşüş varlığını korumaktadır. Bu durum özellikle deney grubunda deneysel çalı̧̧manın etkilerinin devam ettiğini göstermektedir şeklinde düşünülebilir. Bunun yanı sıra kontrol ve plasebo grubunda ise izleme ölçümlerinden alınan puanlar neredeyse ön ölçümden alınan puanlara yakın çıktığı bulunmuştur.

Grupların hangisinin ÇOE-Alt ölçekleri ve Otomatik Düşünceler Ölçeğinden alınan puanlara göre daha etkili olduğunu anlamak için, grupların ikili karşılaştırmalarında uygulanan Mann-Whitney U testi bulguları Tablo $3,4,5,6,7^{\prime}$ da yer almaktadır. 
Tablo 3. Deney, Kontrol ve Plasebo Gruplarının ÇOE- Problemden Ayırma Alt Ölçeği Öntest-Sontest ve Sontest-İzleme Fark Puanlarna İlişkin Mann-Whitney U Testi Sonuçlarn

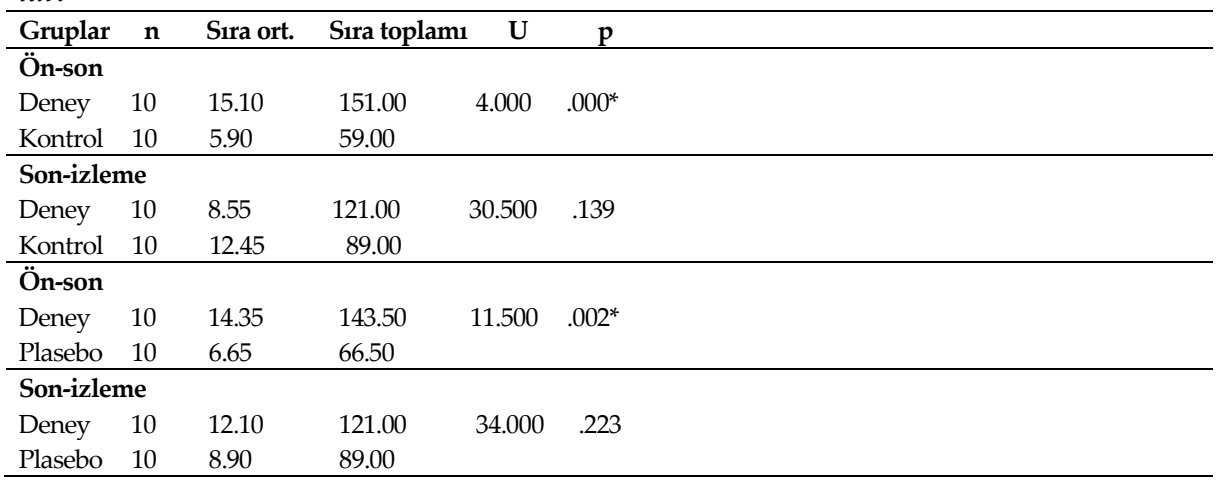

Grupların ÇOE-Problemden Ayırma alt boyutundan aldıkları puanlar arasındaki farkın hangi gruplardan kaynaklandığını belirlemek amacıyla ikili gruplar arasındaki farklar için Mann-Whitney U Testi yapılmıştır. Analiz sonuçları deney grubu ile kontrol grubu ve deney grubu ile plasebo grubu arasında deney grubu lehine anlamlı bir fark olduğunu göstermiştir. ÇOE-problemden ayırma izleme ölçümlerinde deney-kontrol ve deneyplasebo grupları arasında istatistiksel olarak anlamlı bir fark çıkmamıştır. Bu durum deneysel çalışmanın etkilerinin devam ettiğini göstermektedir.

Tablo 4. Deney, Kontrol ve Plasebo Gruplarnnn ÇOE- Hedeflere Yönelim Alt Ölçeği Öntest-Sontest ve Sontest-İzleme Fark Puanlanna İlişkin Mann-Whitney U Testi Sonuçlan

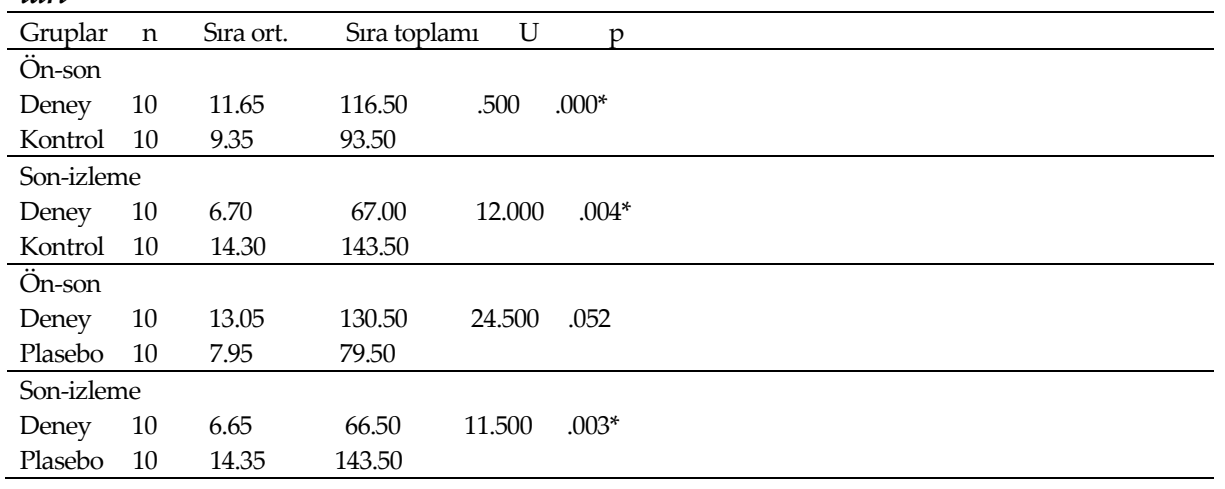


Grupların ÇOE-Hedefe Yönelim alt boyutundan aldıkları puanlar arasındaki farkın hangi gruplardan kaynaklandığını belirlemek amacıyla ikili gruplar arasındaki farklar için Mann-Whitney U Testi yapılmıştır. Analiz sonuçları deney grubu ile kontrol grubu arasında deney grubu lehine anlamlı bir fark olduğunu göstermiştir. Ancak deney grubu ile plasebo grubu arasında istatistiksel olarak sınırda sayılabilecek bir değer elde edilmiştir. ÇOE-Hedefe yönelim izleme ölçümlerinde istatistiksel olarak anamlı bir fark çıkmıştır. Çıkan farkın hangi gruplardan kaynakandığını bulmak için Mann-U yapılmış ve kontrol ve plasebo grubunun hedefe yönelim puanlarında artış olduğu bulunmuştur.

Tablo 5. Deney, Kontrol ve Plasebo Gruplarını ÇOE- Kaynaklarn Harekete Geçirme Alt Ölçeği Öntest-Sontest ve Sontest-İzleme Fark Puanlarına İlişkin Mann-Whitney U Testi Sonuçları

\begin{tabular}{|c|c|c|c|c|c|}
\hline \multirow{2}{*}{$\begin{array}{l}\text { Gruplar } \\
\text { Ön-son }\end{array}$} & \multirow[t]{2}{*}{$\mathbf{n}$} & \multirow[t]{2}{*}{ Sira ort. } & Sira toplamı & \multicolumn{2}{|c|}{$\mathrm{U} \quad \mathrm{p}$} \\
\hline & & & & \multirow{3}{*}{3.5000} & \multirow{3}{*}{$.000^{*}$} \\
\hline Deney & 10 & 15.15 & 151.50 & & \\
\hline Kontrol & 10 & 5.85 & 58.50 & & \\
\hline \multicolumn{6}{|c|}{ Son-izleme } \\
\hline Deney & 10 & 6.85 & 65.60 & 13.500 & $.005^{*}$ \\
\hline Kontrol & 10 & 14.15 & 141.50 & & \\
\hline \multicolumn{6}{|l|}{ Ön-son } \\
\hline Deney & 10 & 11.70 & 117.00 & 38.000 & .393 \\
\hline Plasebo & 10 & 9.30 & 93.00 & & \\
\hline \multicolumn{6}{|c|}{ Son-izleme } \\
\hline Deney & 10 & 6.65 & 66.50 & 11.500 & $.003^{*}$ \\
\hline Plasebo & 10 & 14.35 & 143.50 & & \\
\hline
\end{tabular}

Grupların ÇOE-Kaynakları Harekete Geçirme alt boyutundan aldıkları puanlar arasındaki farkın hangi gruplardan kaynaklandığını belirlemek amaciyla ikili gruplar arasındaki farklar için Mann-Whitney U Testi yapılmıştır. Analiz sonuçları deney grubu ile kontrol grubu arasında deney grubu lehine anlamlı bir fark olduğunu göstermiştir. Ancak deney grubu ile plasebo grubu arasında istatistiksel olarak anlamlı bir fark ortaya çımamıştır. ÇOE-kaynakları harekete geçirme izleme ölçümlerinde istatistiksel olarak anlamlı bir fark çıkmıştır. Çıkan farkın hangi gruplardan kaynakandı̆̆ını bulmak için Mann-U yapılmış ve plasebo grubunun kaynakları harekete geçirme puanlarında artış olduğu bulunmuştur. 
Tablo 6. Deney, Kontrol ve Plasebo Gruplarnn ÇOE- Toplam Puanlarnin ÖntestSontest ve Sontest-İzleme Fark Puanlarna İlişkin Mann-Whitney U Testi Sonuçlan

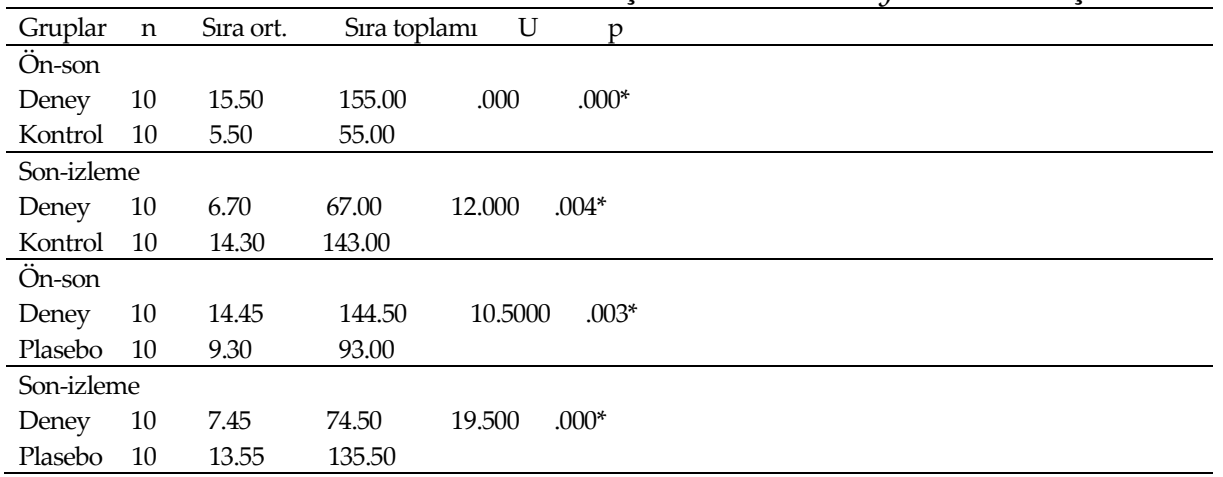

Grupların ÇOE-Toplamdan aldıkları puanlar arasındaki farkın hangi gruplardan kaynaklandığını belirlemek amacıyla ikili gruplar arasındaki farklar için Mann-Whitney U Testi yapılmıştır. Bulgular deney grubu ile kontrol grubu ve deney grubu ile plasebo grubu arasında, deney grubu lehine anlamlı bir fark olduğunu göstermiştir. ÇOE-toplam puan izleme ölçümlerinde istatistiksel olarak anlamlı bir fark çıkmıştır. Çıkan farkın hangi gruplardan kaynakandığını bulmak için Mann-U yapılmış ve kontrol grubunun ÇOE toplam puanlarında düşüş olduğu ve plasebo grubunun puanlarınnıda arttığ

Tablo 7. Deney, Kontrol ve Plasebo Gruplarnnn Otomatik Düşünceler Ölçeği ÖntestSontest ve Sontest-İzleme Fark Puanlarnna İlişkin Mann-Whitney U Testi Sonuçlarn

\begin{tabular}{llllll}
\hline Gruplar & $\mathrm{n}$ & \multicolumn{1}{l}{ Sira ort. } & Sira toplami & $\mathrm{U}$ & $\mathrm{p}$ \\
\hline Ön-son & & & & & \\
Deney & 10 & 5.70 & 57.00 & 2.000 & $.000^{*}$ \\
Kontrol & 10 & 15.30 & 153.00 & & \\
\hline $\begin{array}{l}\text { Son-izleme } \\
\text { Deney }\end{array}$ & 10 & 9.20 & 92.00 & 37.000 & .325 \\
Kontrol & 10 & 11.80 & 118.00 & & \\
\hline $\begin{array}{l}\text { Ön-son } \\
\text { Deney }\end{array}$ & 10 & 9.30 & 93.00 & 38.000 & .393 \\
Plasebo & 10 & 11.70 & 117.00 & & \\
\hline $\begin{array}{l}\text { Son-izleme } \\
\text { Deney }\end{array} 10$ & 8.75 & 87.50 & 32.500 & .186 \\
$\begin{array}{l}\text { Plasebo } \\
10\end{array}$ & 12.25 & 122.50 & & \\
\hline
\end{tabular}

Grupların Otomatik Düşünceler Ölçeğinden aldıkları puanlar arasındaki farkın hangi gruplardan kaynaklandığın belirlemek amacıyla ikili gruplar 
arasındaki farklar için Mann-Whitney U Testi yapılmıştır. Bulgular deney grubu ile kontrol grubu arasında deney grubu lehine anlamlı bir fark olduğunu göstermiştir. Ancak deney grubu ile plasebo grubu arasında anlamlı bir fark bulunmamıştır. Otomatik düşünceler ölçeğinin izleme ölçümlerinden alınan verilere göre istatistiksel olarak anlamlı bir fark çıkmamıştır. Ayrıca deney grubundaki düşüş varlığını korumaktadır. Bu durum özellikle deney grubunda deneysel çalışmanın etkilerinin devam ettiğini göstermektedir şeklinde düşünülebilir.

\section{Çözüm Odaklı Envanter (ÇOE) Toplam Puanlan ve Alt Ölçekleri ile Oto- matik Düşünceler Ölçeğine İlişkin Wilcoxon işaretli Stralar Testi Bulgularn}

Deney, kontrol ve plasebo grubundaki katılımcilardan deney öncesi, deney sonrası ve izleme ölçümleri alınarak, çözüm odaklı eğilimlerinin ve otomatik düşüncelerinin anlamlı bir farklılık ortaya koyup koymadığına ilişkin Wilcoxon İşaretli Sıralar Testi uygulanmış elde edilen bulgular Tablo 8, Tablo 9, Tablo 10, Tablo 11 ve Tablo 12' de verilmiştir.

Araştırmanın 2. Denencesi, "Çözüm odaklı kısa süreli psikolojik danışma programına katılan deney grubundakilerin kontrol ve plasebo grubundakilere göre ÇOE-problemden ayırma alt ölçeği öntest-sontest puanları arasında son test lehine ve sontest-izleme puanları arasinda ise izleme testi lehine anlamlı bir fark olacaktır." için deney, kontrol ve plasebo grubu katılımclarını "problemden ayırma" alt ölçeği öntest-sontest ve sontest-izleme testi puanları arasında istatistiksel olarak anlamlı bir farkın olup olmadığı ilişkili iki ölçüm setine uygulanan Wilcoxon İşaretli Sıralar Testi ile araştırılmış ve elde edilen sonuçlara ilişkin bulgular Tablo 8'de verilmiştir.

Tablo 8. Deney, Kontrol ve Plasebo Grubundaki Katılımcılarn ÇOE-Problemden Ayırma Alt Ölçeği Öntest-Sontest ve Sontest-İzleme Testi Puanlarna İlişkin Wilcoxon İşaretli Sıralar Testi Sonuçlarn

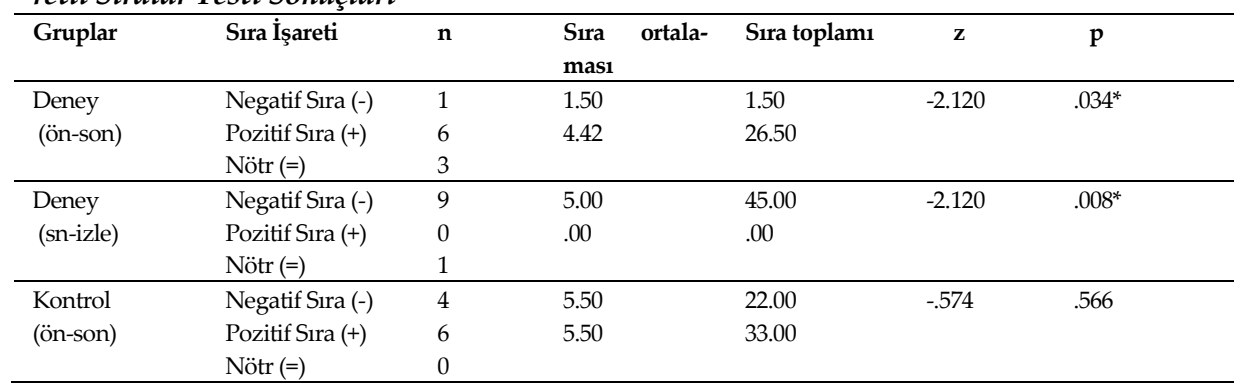




\begin{tabular}{lllllll}
\hline Kontrol & Negatif Sira (-) & 5 & 6.80 & 34.00 & -.666 & .505 \\
(sn-izle) & Pozitif Sira (+) & 5 & 4.20 & 21.00 & & \\
& Nötr (=) & 0 & & & & \\
& Negatif Sira (-) & 6 & 5.00 & 30.00 & .1 .689 & .091 \\
Plasebo & Pozitif Sira (+) & 2 & 3.00 & 6.00 & & \\
\hline ön-son) & Nötr (=) & 2 & & & -1.372 & .170 \\
& Negatif Sira (-) & 2 & 5.50 & 11.00 & & \\
\hline Plasebo & Pozitif Sira (+) & 7 & 4.86 & 34.00 & & \\
\hline
\end{tabular}

* Negatif stralar temeline dayalı

Tablo 8'de verilen Wilcoxon İşaretli Sıralar Testi sonuçlarına göre deney grubunda yer alan katılımcların ÇOE-problemden ayırma puanlarının, ÇOKSPD'ya katılmadan önce ve programa katıldıktan sonra aldıkları puanlar arasında anlamlı bir farklılık olduğu bulunmuştur $(\mathrm{z}=-2.120, \mathrm{p}<0.05)$. Fark puanlarının sıra toplamı dikkate alındığında, gözlenen bu farkın son test puanı lehine olduğu görülmektedir. Sonuçlar denenceyi desteklemekte ve ÇOKSPD, öğrencilerin ÇOE-problemden ayırma alt ölçeği düzeylerinin artmasında etkili olduğunu göstermektedir şeklinde ifade edilebilir. Yapılan izleme ölçümlerinde ise $(\mathrm{z}=-2.120, \mathrm{p}>0.05)$ anlamlı bir düşüş yaşandığı görülmekte ve katılımcıların 4 ay sonra başlangıçtaki puanlarına geri ulaştıklar1 görülmüştür. Kontrol ( $\mathrm{z}=-.574, \mathrm{p}>0.05)$ ve plasebo (son: $\mathrm{z}=-1.689, \mathrm{p}>0.05$; izleme: $\mathrm{z}=-1.372 \mathrm{p}>0.05$ ) gruplarında ise problemden ayırma düzeylerinin artmasında son ve izleme ölçümlerinde bir farklılığın olmadığı söylenebilir.

Araştırmanın 3. Denencesi “Çözüm odaklı kısa süreli psikolojik danışma programına katılan deney grubundakilerin kontrol ve plasebo grubundakilere göre ÇOE-hedefe yönelim alt ölçeği öntest-sontest puanları arasında son test lehine ve sontest-izleme puanları arasinda ise izleme testi lehine anlamlı bir fark olacaktır" için deney, kontrol ve plasebo grubu katılımcıların hedefe yönelim alt ölçeği öntest-sontest ve sontest-izleme testi puanları arasında istatistiksel olarak anlamlı bir farkın olup olmadığı ilişkili iki ölçüm setine uygulanan Wilcoxon İşaretli Sıralar Testi ile araştırılmış ve elde edilen sonuçlara ilişkin bulgular Tablo 9'da verilmiştir.

Tablo 9'da verilen Wilcoxon İşaretli Sıralar Testi sonuçlarına göre deney grubu katılımclların ÇOE-hedefe yönelim düzeylerinin, ÇOKSPD'ya katılmadan önceki ve programa katıldıktan sonraki puanları arasında anlamlı bir farklılık olduğu hesaplanmıştır ( $\mathrm{z}=-2.439, \mathrm{p}<0.05)$. Fark puanlarının sıra toplamı dikkate alındığında, gözlenen bu farkın son test puanı lehine oldu- 
ğu görülmektedir. Sonuçlar denenceyi desteklemekte ve ÇOKSPD, öğrencilerin ÇOE-hedefe yönelim alt ölçeği düzeylerinin artmasında etkili olduğunu göstermektedir şeklinde ifade edilebilir. Yapılan izleme ölçümlerinde ise $(\mathrm{z}=-2.810, \mathrm{p}>0.05)$ anlamlı bir düşüş yaşandığ 1 görülmekte ve katılımciların 4 ay sonra neredeyse başlangıçtaki puanlarına geri ulaştıkları görülmüştür. Kontrol ( $\mathrm{z}=-1.310, \mathrm{p}>0.05$ ) ve plasebo (son: $\mathrm{z}=-1.725, \mathrm{p}>0.05$; izleme: $\mathrm{z}=.000$, $\mathrm{p}>0.05)$ grubunda hedefe yönelim düzeylerinin artmasında son ve izleme ölçümlerinde bir farklılığın olmadığı söylenebilir.

Tablo 9. Deney, Kontrol ve Plasebo Grubundaki Ergenlerin ÇOE-Hedefe Yönelim Alt Ölçeği Öntest-Sontest ve Sontest-İzleme Testi Puanlarna İlişkin Wilcoxon İşaretli Stralar Testi Sonuçlarn

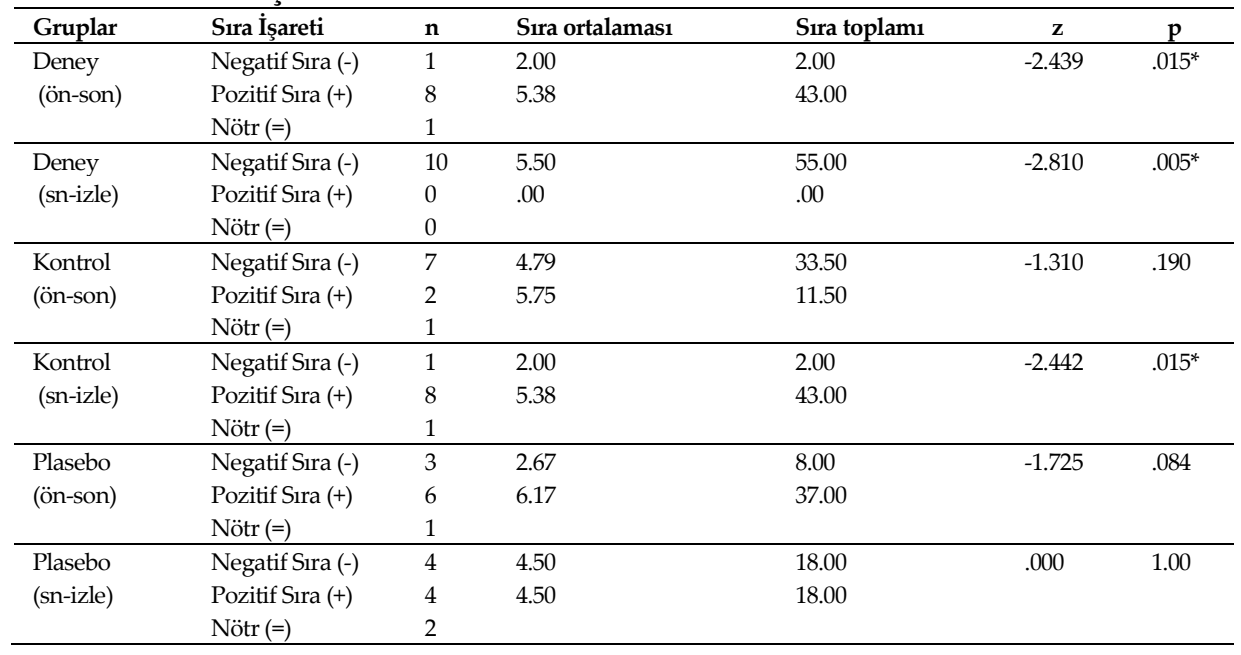

* Negatif stralar temeline dayalı

Araştırmanın 4. Denencesi “Çözüm odaklı kısa süreli psikolojik danışma programina katılan deney grubundakilerin kontrol ve plasebo grubundakilere göre ÇOE-kaynakları harekete geçirme alt ölçeği öntest-sontest puanları arasinda son test lehine ve sontest-izleme puanları arasında ise izleme testi lehine anlamlı bir fark olacaktır" için deney, kontrol ve plasebo grubu katılımcıların kaynakları harekete geçirme alt ölçeği öntest-sontest ve sontestizleme testi puanları arasında istatistiksel olarak anlamlı bir farkın olup olmadığı ilişkili iki ölçüm setine uygulanan Wilcoxon İşaretli Sıralar Testi ile araştırılmış ve elde edilen sonuçlara ilişkin bulgular Tablo 10'da verilmiştir. 
Tablo 10. Deney, Kontrol ve Plasebo Grubundaki Ergenlerin ÇOE-Kaynaklarn Harekete Geçirme Alt Ölçeği Öntest-Sontest ve Sontest-İzleme Testi Puanlarna İlişkin Wilcoxon İşaretli Stralar Testi Sonuçlarn

\begin{tabular}{|c|c|c|c|c|c|c|}
\hline Gruplar & Sıra İşareti & $\mathbf{n}$ & $\begin{array}{l}\text { Sira } \\
\text { ortalaması }\end{array}$ & Sira toplamı & $\mathbf{z}$ & p \\
\hline $\begin{array}{l}\text { Deney } \\
\text { (ön-son) }\end{array}$ & $\begin{array}{l}\text { Negatif Sira (-) } \\
\text { Pozitif Sira (+) } \\
\text { Nötr }(=)\end{array}$ & $\begin{array}{l}2 \\
7 \\
1 \\
\end{array}$ & $\begin{array}{l}2.50 \\
5.71\end{array}$ & $\begin{array}{l}5.00 \\
40.00\end{array}$ & -2.082 & $.037^{*}$ \\
\hline $\begin{array}{l}\text { Deney } \\
\text { (sn-izle) }\end{array}$ & $\begin{array}{l}\text { Negatif Sira (-) } \\
\text { Pozitif Sıra (+) } \\
\text { Nötr }(=)\end{array}$ & $\begin{array}{l}10 \\
0 \\
0 \\
\end{array}$ & $\begin{array}{l}5.50 \\
.00\end{array}$ & $\begin{array}{l}55.00 \\
.00\end{array}$ & -2.821 & $.005^{*}$ \\
\hline $\begin{array}{l}\text { Kontrol } \\
\text { (ön-son) }\end{array}$ & $\begin{array}{l}\text { Negatif Sira (-) } \\
\text { Pozitif Sira (+) } \\
\text { Nötr }(=)\end{array}$ & $\begin{array}{l}7 \\
3 \\
0 \\
\end{array}$ & $\begin{array}{l}5.71 \\
5.00\end{array}$ & $\begin{array}{l}40.00 \\
15.00\end{array}$ & -1.277 & .202 \\
\hline $\begin{array}{l}\text { Kontrol } \\
\text { (sn-izle) }\end{array}$ & $\begin{array}{l}\text { Negatif Sira (-) } \\
\text { Pozitif Sıra (+) } \\
\text { Nötr }(=)\end{array}$ & $\begin{array}{l}2 \\
8 \\
0 \\
\end{array}$ & $\begin{array}{l}4.00 \\
5.88\end{array}$ & $\begin{array}{l}8.00 \\
47.00\end{array}$ & -1.998 & $.046^{*}$ \\
\hline $\begin{array}{l}\text { Plasebo } \\
\text { (Ön-son) }\end{array}$ & $\begin{array}{l}\text { Negatif Sira (-) } \\
\text { Pozitif Sira (+) } \\
\text { Nötr }(=)\end{array}$ & $\begin{array}{l}1 \\
4 \\
5 \\
\end{array}$ & $\begin{array}{l}2.00 \\
3.25\end{array}$ & $\begin{array}{l}2.00 \\
13.00\end{array}$ & -1.511 & .131 \\
\hline $\begin{array}{l}\text { Plasebo } \\
\text { (sn-izle) }\end{array}$ & $\begin{array}{l}\text { Negatif Sira (-) } \\
\text { Pozitif Sira (+) } \\
\text { Nötr }(=)\end{array}$ & $\begin{array}{l}7 \\
1 \\
2 \\
\end{array}$ & $\begin{array}{l}4.57 \\
4.00\end{array}$ & $\begin{array}{l}32.00 \\
4.00\end{array}$ & -1.975 & .048 \\
\hline
\end{tabular}

* Negatif stralar temeline dayalı

Tablo 10'da verilen Wilcoxon İşaretli Sıralar Testi sonuçlarına göre deney grubu katılımcıların ÇOE-kaynakları harekete geçirme düzeylerinin, ÇOKSPD'ya katılmadan önceki ve programa katıldıktan sonraki puanları arasında anlamlı bir farklılık olduğu görülmektedir $(\mathrm{z}=-2.082, \mathrm{p}<0.05)$. Fark puanlarının sıra toplamı dikkate alındığında, gözlenen bu farkın son test puanı lehine olduğu görülmektedir. Sonuçlar denenceyi desteklemekte ve ÇOKSPD, öğrencilerin ÇOE-kaynakları harekete geçirme alt ölçeği düzeylerinin artmasında etkili olduğunu göstermektedir şeklinde ifade edilebilir. Yapılan izleme ölçümlerinde ise $(\mathrm{z}=-2.821, \mathrm{p}>0.05)$ anlamlı bir düşüş yaşandığı görülmekte ve katılımclların 4 ay sonra neredeyse başlangıçtaki puanlarına geri ulaştıkları görülmüştür. Kontrol $(\mathrm{z}=-1.277, \mathrm{p}>0.05)$ ve plasebo (son: $\mathrm{z}=-1.511, \mathrm{p}>0.05$; izleme: $\mathrm{z}=-1.975, \mathrm{p}<0.05$ ) grubunda kaynakları harekete geçirme düzeylerinin artmasında ilk ölçümden son ölçüme bir farklılığın olmadığı, ancak son ölçümden izleme ölçümüne kadar ise bir farklılığın olduğu söylenebilir. Aritmetik ortalamalar incelendiğinde ortaya çıkan bu anlamlı farkın azalma yönünde olduğu görülmektedir. 
Araştırmanın 5. denencesi “Çözüm odaklı kısa süreli psikolojik danışma programina katılan deney grubundakilerin kontrol ve plasebo grubundakilere göre ÇOE-toplam öntest-sontest puanları arasında son test lehine ve sontest-izleme puanları arasında ise izleme testi lehine anlamlı bir fark olacaktır." için deney, kontrol ve plasebo grubu katılımcların ÇOE-toplam öntest-sontest ve sontest-izleme testi puanları arasında istatistiksel olarak anlamlı bir farkın olup olmadığı ilişkili iki ölçüm setine uygulanan Wilcoxon İşaretli Sıralar Testi ile araştırılmış ve elde edilen sonuçlara ilişkin bulgular Tablo 11'de verilmiştir.

Tablo 11. Deney, Kontrol ve Plasebo Grubundaki Ergenlerin ÇOE-Toplam Öntest-Sontest ve Sontest-İzleme Testi Puanlarna İlişkin Wilcoxon İşaretli Stralar Testi Sonuçlan

\begin{tabular}{|c|c|c|c|c|c|c|}
\hline Gruplar & Sıra İşareti & $\mathbf{n}$ & Sira ortalaması & Sira toplamı & $\mathbf{z}$ & $\mathbf{p}$ \\
\hline $\begin{array}{l}\text { Deney } \\
\text { (ön-son) }\end{array}$ & $\begin{array}{l}\text { Negatif Sira (-) } \\
\text { Pozitif Sira }(+) \\
\text { Nötr }(=)\end{array}$ & $\begin{array}{l}0 \\
10 \\
0 \\
\end{array}$ & $\begin{array}{l}.00 \\
5.50\end{array}$ & $\begin{array}{l}.00 \\
55.00\end{array}$ & -2.803 & .005 \\
\hline $\begin{array}{l}\text { Deney } \\
\text { (sn-izle) }\end{array}$ & $\begin{array}{l}\text { Negatif Sira (-) } \\
\text { Pozitif Sira (+) } \\
\text { Nötr }(=)\end{array}$ & $\begin{array}{l}10 \\
0 \\
0 \\
\end{array}$ & $\begin{array}{l}5.50 \\
.00\end{array}$ & $\begin{array}{l}55.00 \\
.00\end{array}$ & -2.812 & .005 \\
\hline $\begin{array}{l}\text { Kontrol } \\
\text { (ön-son) }\end{array}$ & $\begin{array}{l}\text { Negatif Sira (-) } \\
\text { Pozitif Sira }(+) \\
\text { Nötr }(=)\end{array}$ & $\begin{array}{l}7 \\
3 \\
0 \\
\end{array}$ & $\begin{array}{l}5.57 \\
5.33\end{array}$ & $\begin{array}{l}39.00 \\
16.00\end{array}$ & -1.176 & .240 \\
\hline $\begin{array}{l}\text { Kontrol } \\
\text { (sn-izle) }\end{array}$ & $\begin{array}{l}\text { Negatif Sira (-) } \\
\text { Pozitif Sıra (+) } \\
\text { Nötr }(=)\end{array}$ & $\begin{array}{l}1 \\
7 \\
2 \\
\end{array}$ & $\begin{array}{l}2.00 \\
4.86\end{array}$ & $\begin{array}{l}2.00 \\
34.00\end{array}$ & -2.243 & $.025^{*}$ \\
\hline $\begin{array}{l}\text { Plasebo } \\
\text { (ön-son) }\end{array}$ & $\begin{array}{l}\text { Negatif Sira (-) } \\
\text { Pozitif Sira (+) } \\
\text { Nötr (=) }\end{array}$ & $\begin{array}{l}6 \\
2 \\
2 \\
\end{array}$ & $\begin{array}{l}2.88 \\
6.13\end{array}$ & $\begin{array}{l}11.50 \\
24.50\end{array}$ & -.912 & .362 \\
\hline $\begin{array}{l}\text { Plasebo } \\
\text { (sn-izle) }\end{array}$ & $\begin{array}{l}\text { Negatif Sira (-) } \\
\text { Pozitif Sira (+) } \\
\text { Nötr }(=)\end{array}$ & $\begin{array}{l}3 \\
7 \\
0\end{array}$ & $\begin{array}{l}7.67 \\
4.57\end{array}$ & $\begin{array}{l}23.00 \\
32.00\end{array}$ & -.459 & .646 \\
\hline
\end{tabular}

* Negatif stralar temeline dayal

Tablo 11'de verilen Wilcoxon İşaretli Sıralar Testi sonuçlarına göre deney grubu katılımcıların ÇOE-toplam düzeylerinin, ÇOKSPD'ya katılmadan önceki ve programa katıldıktan sonraki puanları arasında anlamlı bir farkl1lik olduğu görülmektedir $(\mathrm{z}=-2.803, \mathrm{p}<0.05)$. Fark puanlarının sıra toplamı dikkate alındığında, gözlenen bu farkın son test puanı lehine olduğu görülmektedir. Sonuçlar denenceyi desteklemekte ve ÇOKSPD, öğrencilerin ÇOE-toplam düzeylerinin artmasında etkili olduğunu göstermektedir şeklinde ifade edilebilir. Yapılan izleme ölçümlerinde ise $(z=-2.120, p>0.05)$ anlamlı bir düşüş yaşandığı görülmekte ve katılımciların 4 ay sonra neredeyse başlangıçtaki puanlarına geri ulaştıkları görülmüştür. Kontrol (z= - 
1.176, $p>0.05$ ) ve plasebo (ön: $z=-.912, p>0.05$; son $z=-.459, p>0.05$ ) grubunda ÇOE-toplam düzeylerinin artmasında bir farklılığın görülmediği söylenebilir.

Araştırmanın 6. denencesi “Çözüm odaklı kısa süreli psikolojik danışma programina katılan deney grubundakilerin kontrol ve plasebo grubundakilere göre otomatik düşünceler ölçeği öntest-sontest ve sontest-izleme testi puanları arasında son test lehine sontest-izleme puanları arasında ise izleme testi lehine anlamlı bir fark olacaktır." için deney, kontrol ve plasebo grubu katılımcıların otomatik düşünceler ölçeği öntest-sontest ve sontest-izleme puanları arasında istatistiksel olarak anlamlı bir farkın olup olmadığı ilişkili iki ölçüm setine uygulanan Wilcoxon İşaretli Sıralar Testi ile araştırılmış ve elde edilen sonuçlara ilişkin bulgular Tablo 12' de verilmiştir.

Tablo 12. Deney, Kontrol ve Plasebo Grubundaki Katılımcılarn Otomatik Düşünceler Ölçeği Öntest-Sontest ve Sontest-İzleme Testi Puanlarına İlişkin Wilcoxon İşaretli Sıralar Testi Sonuçları

\begin{tabular}{|c|c|c|c|c|c|c|}
\hline Gruplar & Sıra İşareti & $\mathrm{n}$ & Sira ortalamas1 & Sira toplamı & $\mathbf{z}$ & $\mathrm{p}$ \\
\hline \multirow{3}{*}{$\begin{array}{l}\text { Deney } \\
\text { (ön-son) }\end{array}$} & Negatif Sira (-) & 9 & 5.44 & 49.00 & -2.193 & .028 \\
\hline & Pozitif Sıra (+) & 1 & 6.00 & 6.00 & & \\
\hline & Nötr $(=)$ & 0 & & & & \\
\hline \multirow{3}{*}{$\begin{array}{l}\text { Deney } \\
\text { (sn-izle) }\end{array}$} & Negatif Sira (-) & 5 & 4.40 & 22.00 & -2.193 & .575 \\
\hline & Pozitif Sira (+) & 5 & 6.60 & 33.00 & & \\
\hline & Nötr (=) & 0 & & & & \\
\hline \multirow{3}{*}{$\begin{array}{l}\text { Kontrol } \\
\text { (Ön-son) }\end{array}$} & Negatif Sira (-) & 1 & 2.00 & 2.00 & -2.599 & .009 \\
\hline & Pozitif Sira (+) & 9 & 5.89 & 53.00 & & \\
\hline & Nötr $(=)$ & 0 & & & & \\
\hline \multirow{3}{*}{$\begin{array}{l}\text { Kontrol } \\
\text { (sn-izle) }\end{array}$} & Negatif Sira (-) & 8 & 6.25 & 50.00 & -2.293 & $.002^{*}$ \\
\hline & Pozitif Sıra (+) & 2 & 2.50 & 5.00 & & \\
\hline & Nötr $(=)$ & 0 & & & & \\
\hline \multirow{3}{*}{$\begin{array}{l}\text { Plasebo } \\
\text { (ön-son) }\end{array}$} & Negatif Sira (-) & 4 & 6.13 & 24.50 & -.237 & .813 \\
\hline & Pozitif Sira (+) & 5 & 4.10 & 26.50 & & \\
\hline & Nötr $(=)$ & 1 & & & & \\
\hline \multirow{3}{*}{$\begin{array}{l}\text { Plasebo } \\
\text { (sn-izle) }\end{array}$} & Negatif Sıra (-) & 5 & 4.60 & 23.00 & -.459 & .646 \\
\hline & Pozitif Sira (+) & 5 & 6.40 & 32.00 & & \\
\hline & Nötr (=) & 0 & & & & \\
\hline
\end{tabular}

* Negatif stralar temeline dayalı

Tablo 12'de verilen Wilcoxon İşaretli Sıralar Testi sonuçlarına göre deney grubu katılımclların Otomatik Düşünceler düzeylerinin, ÇOKSPD'ya katılmadan önceki ve programa katıldıktan sonraki puanları arasında anlamlı bir farklılık olduğu görülmektedir $(\mathrm{z}=-2.193, \mathrm{p}<0.05)$. Fark puanlarının sıra toplamı dikkate alındığında, gözlenen bu farkın son test puanı lehine oldu- 
ğu görülmektedir. Sonuçlar denenceyi desteklemekte ve ÇOKSPD, öğrencilerin otomatik düşünceler düzeylerinin azalmasında etkili olduğunu göstermektedir şeklinde ifade edilebilir. Yapılan izleme ölçümlerinde ise ( $\mathrm{z}=$ 2.193, $\mathrm{p}<0.05$ ) otomatik düşüncelerdeki anlamlı azalmanın 4 ay sonra da devam ettiği görülmüştür. Kontrol grubunda ise $(z=-.2 .599, p<0.05)$ istatistiksel olarak ortaya çıkan fark incelendiğinde kontrol grubu öğrencilerinin otomatik düşüncelerinde bir artı̧ olduğu görülmektedir ve plasebo grubunda ise (son: $z=-.237, p>0.05$; izleme: $z=-.459$, $p>0.05$ ) otomatik düşünceler düzeylerinin düşmesinde bir farklılığın görülmediği söylenebilir.

\section{Tartışma}

Araştırmadan elde edilen bulgular incelendiğinde, deney, kontrol ve plasebo grubunda yer alan öğrencilerin ön test, son test ve izleme ölçümleri göz önüne alınarak ortaya çıan sonuçlar şöyledir; ÇOKSPD'nın uygulandığı deney grubunda yer alan öğrenciler kontrol grubunda yer alan öğrencilerle karşılaştırılmış Otomatik Düşünceler Ölçeği'nin (ODÖ) ön test-son test puan ortalamaları arasında deney grubu lehine anlamlı farklar bulunmuştur. Elde edilen bulgular ÇOKSPD'nin deney grubundaki öğrencilerinin otomatik düşünceler puanlarını azaltmada etkili olduğunu göstermiştir. Bunun yanisıra kontrol grubu ile plasebo grubu arasinda ise kontrol grubu lehine anlamlı bir fark olduğu hesaplanmıştır. Veriler incelendiğinde anlamlı farkın kaynağının kontrol grubundaki otomatik düşüncelerde artıştan dolayı ortaya çıktı̆ı görülmektedir.

Yine ÇOKSPD'nın deney grubundaki öğrencilerin Çözüm Odaklı Envanteri'nin (ÇOE) genel toplam ve probleme odaklanma, hedefe yönelim ve kaynakları harekete geçirme olan 3 alt boyutu puanlarını arttırmada etkili olduğunu göstermektedir. Araştırmada olumlu sonuçlar ortaya çıaran ÇOKSPD programının, otomatik düşünceleri azaltma ve çözüm odaklı olma eğilimlerini arttırmada uzun süreli etkisinin belirlenebilmesi amacıyla yirmi hafta aradan sonra izleme ölçümleri yapılmıştır. Deney grubuna uygulanan 6 haftalık programın sona ermesinden onaltı hafta sonra, otomatik düşünceler ölçeği ve çözüm odaklı envanter yeniden verilerek izleme ölçümü alınmıştır. Bu sonuçlara göre deney grubunda uygulanan ÇOKSPD programının olumlu etkilerinin devam ettiği şeklinde yorumlanabilir.

ÇOKSPD'nin bireyler üzerindeki etkisi, yapılan pek çok araştırma ve meta-analiz çalışmasında incelenmiştir. Buna göre Kim (2008) tarafından 22 
araştırmanın meta-analiz sonuçlarına göre yaklaşımın davranışsal problemlerin sağaltımında oldukça işlevsel olduğu saptanırken, Gingerich ve Peterson' in (2012) betimsel nitelikli 43 çalışması -çocukların akademik ve davranış sorunları (14 çalışma), erişkin ruh sağlı̆̆ (10 çalışma), evlilik ve aile (6 çalışma), mesleki rehabilitasyon (5 çalışma), sağlık ve yaşlanma (5 çalışma), suç ve suçluluk (4 çalışma) - ise yaklaşımın, bireylerin sorunlarının çözümünde pozitif yönde $\% 74$ etkili olduğunu göstermiştir. 43 çalışmanın 32'sinde ÇOKSPD'nin bireyler üzerindeki sağaltıcı etkisi bulgulanmıştır. Bu araştırmaların yanı sıra Yuan ve arkadaşlarının (2015) yaptığı çalışmada ise kayıp yaşamış olan yaslı bireylerin yaşadıkları üzücü süreci aşmalarına dönük ÇOKSPD'den yararlanılmış ve danışma alan bireylerin yaşadıkları sürecin daha güçlü bir şekilde üstesinden geldikleri, sürece karşı olan bakış açılarının kendilerini sağaltıı yönde değiştiği saptanmıştır. Çalışmada özellikle bireylerin yeniden karar verme, kendini düzenleme ve değişiklik süreçlerinin belirgin olarak pozitif yönlü değişimler içerdiği de dikkat çekmekte, kendilerini keder ve bunun verdiği zarardan kurtarma konusunda güçlü bir şekilde yetkinleştikleri görülmektedir.

Aile/çift terapisi, bireysel danışmalar ve grup danışmaları, cinsel terapi, cinsel istismar vakaları, akıl sağlı̆̆ı, madde kullanımı, yeme bozuklukları, şizofreni tedavisi gibi farklı alanlarda hatta kişisel gelişim kitaplarında dahi işlevsel olarak kullanılan çözüm odaklı terapinin (Smith, 2010) uygulandığı özgün bir araştırmanın da psikiyatri koğuşunda yatan bir hastayla yapıldığı görülmektedir. Rhodes ve Jakes (2002) tarafından yapılan çalışmada şeytanların kendisini ziyaret ettiğine inanan bir danışan ile çalışılmış ve süreçte danışanın etkileyici bir değişime girerek günlük aktivitelerini olumlu yönde geliştirdiği ve otomatik inançlarını değiştirdiği kaydedilmiştir. Çözüm odaklı yaklaşımın uygulanmaya başlandığı tarihten günümüze kadar olan süreçte, bu danışma modelinin hemen hemen tüm problem türlerinde etkili olduğu (Iveson, 2002) ve özellikle danışanların güçlü yönlerine odaklanılması bağlamında mümkün olan en kısa sürede olumlu geri bildirimler alındığ1 (Rotwell, 2005) düşünülmektedir. Lindforss ve Magnusson tarafindan (1997) İsveç' te bulunan bir hapishanedeki suçlularla çözüm odaklı yaklaşım çalışmış ve çalışmada deney grubundaki suçluların kontrol grubuna göre yeni bir suça tekrar girme oranlarının anlamlı derecede düştüğü görülmüştür. 
Piercy, Lipchik ve Kiser' e (2000) göre çözüm odaklı yaklaşımı benimseyen danışmanlar, danışanların duygularının yanında düşüncelerine de odaklanmalı, başka bir ifadeyle hem duygu hem de düşünce birlikte çalışmalıdır. Duygu, davranış ve biliş süreçleri, danışanların kendi yaşantılarıyla ilgili farklı yönleri ifade etse de (Kiser vd., 1993; Lipchik, 1999) bunun yanı sıra danışanların yaşamlarında "duygusal uyum"a yöneldikleri görülmektedir (Bowers, 1981). Danışanların hissettiği olumsuz duygular ise geçmişe, şimdiye ve gelecekteki yaşamlarına yönelik olumsuz bakış açlarıyla ilişkilidir. Çözüm odaklı yaklaşım, danışanların duygu, biliş ve davranışları arasındaki bağlantıları vurgulamakta, olumsuz duygu ve bakış açları için pratik çözümler üretebilmelerini sağlamakta (Miller ve Shazer, 2000) ve çözüm odaklı düşünce, bireylerin çeşitli durumlara uyum sağlamasında oldukça etkili gözükmektedir (Hosseinpour, Jadidi, Mirzaian ve Hoseiny, 2016).

Tıbbi yardım alan hastalara yönelik yapılan ve çözüm odaklı kısa süreli terapinin kullanıldığı araştırmaların meta analizini yapan Zhang ve arkadaşları (2017), ÇOKSPD'nin hastalar üzerindeki psikososyal sonuçlarını incelemiş ve genel olarak bu yaklaşımın hastalar üzerinde olumlu, önemli bir etkisinin olduğunu bulmuştır. Terapilerin hastaların psikososyal durumlarında meydana getirdiği sağaltıcı etkinin yanı sıra terapilerle hasta davranışlarının da olumlu bir eğilime girdiği saptanmıştır. Bireylerin psikolojik sorunlarını içselleştirmesi ile bu

sorunların yine birey tarafından davranışsal bağlamda dışsallaştırılması arasındaki güçlü ilişki (Dutton ve Karakanta, 2013; Eisenberg vd., 2001) düşünüldüğünde ÇOKSPD yaklaşımının davranış üzerindeki olumlu etkisinin içsel süreçlere de yansıması kaçınılmaz gözükmektedir (Zhang vd., 2017).

Sharry, Darmody ve Madden (2002) kendine zarar verme - intihar eğilimli hastalarla yaptıkları bir araştırmada çözüm odaklı yaklaşımı kullanmışlar; amaç olarak ise danışanların güçlü yönlerini ortaya çlkarma, sorunlarıyla baş etme becerilerini geliştirme, anlamlı hedefler belirleme ve olumlu bir gelecek kurmaya dönük öngörülerini geliştirmeye odaklanmışlardır. Sonuç olarak ilaç tedavisi ile birlikte yürütülen çözüm odaklı yaklaşımın hastalar üzerindeki olumlu etkisinin, diğer geleneksel modellere göre daha işlevsel olduğu ve yaklaşımın değişimi kolaylaştırdığı bulgulanmıştır.

Çözüm odaklı çalışmalar incelediğinde, kendine uygun ve gerçekçi hedefler belirleyebilen, bulduğu çözümlerin uygulayabilen ve potansiyelini 
doğru bir şekilde kullanabilen bir üniversite öğrencisi akademik başarı gösterebilir, kişilerarası ilişkiler kurabilir ve yaşamının olumlu yanlarını görebilir (Perry, 2014). Meydan (2013) ise, çözüm odaklı yaklaşımın öğrenciler üzerinde olumlu etkileri olduğunu görmüştür. Bu olumlu etkiler, öğrencilerin daha düşük düzeyde depresyon yaşamalarını sağlarken hedefe ulaşma düzeylerinde artış göstermiştir. Öğrencilerin anksiyete, stres, depresyon ve problemi çözememe gibi sorunların çözüme kavuşmasında çözüm odaklı düşünmenin etkili olduğuna ilişkin görüşler vardır (Gingerich ve Peterson, 2013; Grant, 2013; Kramer ve diğ., 2015; Bilge ve Engin, 2016; Reddy ve diğ., 2015; Carr, Smith ve Simm, 2014; Valve ve diğ., 2013; Davies, Morriss ve Glazebrook, 2014); alkol bağımlılığı (Spilsbury, 2012); saldırganlık eğilimleri ve şiddetin olumsuz sonuçların giderebilme (Bulut, 2008; Atasayar, Bilgin ve Berberoğlu, 2010); öfke kontrolü (Tuna, 2012); davranış problemleri (Franklin, Moore ve Hopson, 2008; Corcoran, 2006), sinav kayg1sı (İşlek, 2006; Atasayar ve Bilgin, 2010); akademik güçlükler ve akademik başarıyı arttırmada (Daki ve Savage, 2010; Utterback, 2011); benlik algisı (Grant ve O'Connor 2010); hayata umutla bakma ve boyun eğici davranışların azalmasında (Köktuna, 2007); psikolojik iyi oluş (Seidel \& Hedley, 2008) kişilerarası ilişkiler (Reimer ve Chatwin, 2006); sosyal fobi ile başa çımada (George, 2008; Ateş, 2014); güvengenlik becerisini arttırmada (Ateş, 2015); problem çözmede artış ve sınav kaygısında azalma (Sarıcı-Bulut, 2008; İşlek, 2006); Üniversite öğrencilerinin ruminasyon düzeylerinin azaldığı (Sarıçam, 2014); tükenmişlik düzeylerini düşürdüğü (İlbay, 2014), Grant ise (2008) bir çalışmasında, ÇOT'un katılımcıların hedefi belirleme ve hedefe ulaşma düzeyinde yükseliş sağladığı, ancak psikolojik iyi oluş düzeylerinde ise bir değişim sağlamadığını belirtmiştir. Çözüm odaklı kısa süreli terapi/psikolojik danışma ile ilgili alanyazın tarandığında çözüm odaklı kısa süreli terapi odaklı grupla psikolojik danışma ve psiko-eğitim programlarının yurtiçinde ve yurt dişında olumlu sonuçlar verdiği görülmektedir.

Benzer şekilde deneysel çalışmalar ve güncel bazı programlar öğrencilerin olumsuz otomatik düşüncelerinin azaltılmasında önleyici ve iyileştirici bir rol oynayabilmektedir. Bu çalışmalardan birinde, 14 hafta mindfulness (farkındalık) meditasyon eğitimi verilen 39 üniversite öğrencilerinin otomatik düşüncelerinin azaldığı ve yaşam doyumlarının arttı̆ıın bulunmuştur (Ritvo, Vora, Irvine, Mongrain, Azargive, Azam, Pirbaglou, Guglietti, Wayne, Perez, ve Cribbie, 2013). Bir diğer çalışmada, Cho, Ryu, Noh, Lee (2016), 
Japonya'da günlük nefes alma egzersizlerinin üniversite öğrencilerinin sonav kaygısı ve pozitif otomatik düşüncelere etkisini inceledikleri çalışmalarında, nefes alma egzersizi sayesinde öğrencilerin pozitif olumlu düşünmeyi arttırdığı yönünde bir sonuca ulaşmışlardır. Bir diğer çalışmada ise, 12 hafta boyunca web tabanlı bilişsel davranışçı terapisi uygulanan üniversite öğrencilerinin mükemmeliyetçilik, kaygı, depresyon, olumsuz otomatik düşünce ve algılanan stres düzeyleri araştırılmış ve, bilişsel davranış̧̧ terapinin mükemmeliyetçilik ve olumsuz otomatik düşüncelerin düşmesinde anlamlı etkileri olduğunu bulmuşlardır (Radhu, Zafiris, Daskalakis, ArpinCribbie, Phil, Ritvo, 2012). Kabul ve kararlılık terapisi (ACT) uygulanan 22 üniversite öğrencisinin 12 seans sonunda depresif belirtiler, özgüven ve olumsuz otomatik düşüncelerde olumlu etkilerinin olduğunun ortaya koymuştur (Hinton ve Gaynor, 2010). Lappalainen, Langrial, Oinas-Kukkonen, Tolvanen ve Lappalainen (2015), tarafından web temelli yapılan bir diğer kabul ve kararlılık terapisinde ise, 39 psikoloji bölümü öğrencisiyle gerçekleştirdikleri deneysel çalışmalarında, 7 haftalık müdahele programlarının ardından 12 aylık takip sonrası, öğrencilerin, depresif belirtilerinin ve olumsuz otomatik düşüncelerinin azaldığı bulunmuştur. Varol, Karakaş, Bedel (2015), 8 hafta süresince ve 11 üniversite öğrencisinden oluşan deney grubuyla yaptıkları çalışmada, stresle başa çımma eğitiminin olumsuz otomatik düşünmeyi azaltmada etkili olduğunu bulmuşlardır. Meriç ve Oflaz (2013), bilişsel yaklaşım temelinde yaptıkları araştırmalarında ise yaygın anksiyete tanısı bireylerin otomatik düşüncelerinin anlamlı düzeyde azaldığını bulmuşlardır.

Bulgular incelendiğinde, ÇOKSPD'nın, katılımclların otomatik düşüncelerinin azaltılmasında etkili olduğu söylenebilir. Elde edilen bu sonuçlar hem yurt içinde hem de yurt dışında yapılan bazı benzer çalışmalarla desteklenmektedir (Demirci, ve Erden, 2016; Duarte, Miyazaki, Blay, \& Sesso, 2009; Gruber, Moran, Roth, \& Taylor, 2001; Norton, 2008; Sapmaz, 2011; Sertelin Mercan, 2007; Sütcü, Aydın, ve Sorias, 2010; Taube-Schiff, Suvak, Antony, Bieling, \& McCabe, 2007; Thienemann, Martin, Cregger, Thompson, \& Dyer-Friedman, 2001; Hiçdurmaz, 2001; Gültekin, 2014).

Bilişsel bakış açısına göre terapide amaç danışanların otomatik düşüncelerinin yerine kendilerinin akılcı ve alternatif açıklamalar koyabilir hale gelmesini sağlamaktır (Türkçapar, 2014). Bireyler otomatik düşüncelerinin farkına vardıklarında, düşüncelerinin geçerliliğini ve işlevini de farketmeye 
başlarlar. İşlevsel olmayan otomatik düşüncelerini fark eden birey objektif bir değerlendirme yaparak duygu durumu ve davranışlarını da değiştirebilecek alternatif ve işlevsel bir düşünce sistemine geçebilir (Beck, 2014). Bu grup çalışmasına katılan bireylerin yani deney grubundaki katılımcıların otomatik düşüncelerini tanımaları, bilişsel çarpıtmalarını bulmaları, alternatif açıklamalar yapabilmeleri için teknikler kullanılarak ve ev ödevleri verilerek katılımcların yeni bir düşünce şeması ve aynı zamanda olumlu bir düşünce şeması edinmelerine yardımcı olunmaya çalışılmıştır. Bu araştırmada da ÇOKSPD'nın deneklerin otomatik düşüncelerini azaltmada ve devam ettirmede etkili olduğunu göstermektedir. Ayrıca çözüm odaklı toplam puanında, probleme odaklanma, hedefe belirleme ve kaynakları harekete geçirmede de olumlu artışın olduğu ve bu durumun izleme ölçümlerinde de devam ettiği bulunmuştur. Görüldüğü gibi alan yazındaki bir çok araştırmanın bulgusu bu araştırmanın bulguları ile paralellik göstermektedir. Katılımcların oturumlara aksatmadan ve gönüllü olarak gelmeleri bunun yanı sıra programın içeriğine uygun davranıp direnç göstermeyerek önemli katkılar sundukları düşünülmektedir.

Sonuç olarak Türkiye'de rehberlik ve psikolojik danışmanlık programlarını tamamlayan, psikolojik danışmanların büyük bir bölümü okullarda, okul psikolojik danışmanı olarak görev yapmaktadır. Bu nedenle çözüm odaklı kısa süreli psikolojik danışma yaklaşımının hem kuramsal hem de uygulamalı olarak öğrencilere öğretecek bir seçmeli dersin programa eklenmesi düşünülebilir. Ayrıca deneysel çalışmaların Türkiye'de yetersiz olduğu da görülmektedir.

\section{Öneriler}

Bu çalışmadan ortaya çıkan sonuçlara göre yeni yapılacak araştırmalarda, RPD programında eğitim gören öğrencilerle farklı psikolojik danışma kuramları temelinde farklı sınıf düzeylerinde grupla psikolojik danışma programlarının etkisi incelenebilir. Ayrıca bilinmektedir ki; uzun dönemli programların kısa dönemli programlara göre etkisi çok daha fazladır. Bundan dolayı uzun dönemli programların yapılması önerilebilir. İleriki zamanlarda yapılacak çalışmalarda ek oturumlar periyodik olarak uygulanarak pekiştiricilik sağlanabilir ve uzun dönem sonundaki etkisi araştırılabilir. Psikolojik Danışman (okul psikolojik danışmanı ve/veya okul psikolğu) adaylarına 
mesleklerini yerine getirirken kendi grup çalışmalarında kullanabilmeleri için çözüm odaklı psikolojik danışma hem kuramsal hem de uygulamalı olarak daha detaylı bir şekilde RPD lisans programlarında yer verilerek öğretilebilir.

Bir diğer açıdan bakıldığında ise farklı üniversitelerde ve farklı sınıf düzeylerinde araştırmaların sayısının arttırılması gerektiği ortaya çıkmaktadır. Çözüm odaklı psikolojik danışma kuramının uygulama süreci gibi diğer birçok psikolojik danışma kuramlarının uygulama süreçleri lisans programlarında yer alabilir. Çözüm odaklı psikolojik danışma ve diğer psikolojik danışma yöntem ve teknikleri psikolojik danışman adaylarının göreve başlamadan önce kendilerinde uygulamaları gereken kuramlardır. Bir psikolojik danışman adayının ilk olarak kendisinin psikolojik danışma sürecinden geçmesi gerektiği unutulmamalıdır. Ülkemizdeki psikolojik danışman eğitimindeki en önemli eksiklerden birisi de budur. Bu nedenle her psikolojik danışman adayının böyle bir süreçten (bireysel ya da grupla psikolojik danışma) geçmelerinin faydalı olacağı düşünülmektedir. Bu nedenle, buna benzer psikolojik danışma kuramlarının uygulanmasında üniversitedeki akademisyenlerin ve alanda görev yapan psikolojik danışmanların önemli görevleri olacağı düşünülmektedir.

\section{Sinurlılıklar}

Bu çalışmanın bazı sınırlılıkları bulunmaktadır. Bu araştırma Aksaray Üniversitesi RPD ana bilim dalında öğrenim gören öğrenciler ile sınırlıdır. Çalışmanın bir diğer sinırlılığı ise izleme ölçümünün daha uzun zaman sonunda yapılmamış olmasıdır. Bu nedenle araştırmanın sonuçlarının daha uzun süreli etkisinin incelenmemiş olması bir sınırlılıktır. Bundan sonra yapılacak araştırmalarda bu sınırlılıkların dikkate alınması önerilebilir. 


\title{
EXTENDED ABSTRACT \\ The Effect of Solution-Focused Group Counseling with Psychological Counselor Candidates on Solution-Focused Tendency and Automatic Thoughts
}

\author{
Rezzan Gündoğdu \\ Aksaray Üniversitesi
}

Trying to adapt to today's world, to exist and to be spiritually and physically healthy, humankind seems willing to develop new ways of thinking and try different solutions in order to find their own solutions, to understand themselves and the world and to live a more meaningful life. To this end, psychological counseling and/or therapy processes that help individuals with searches and efforts work on different approaches. The solutionoriented approach is one of these different approaches. Based on individuals' resources and resilience, solution-focused approach shows how the client can use these following the path of purposeful and positive change. Although there has been a growing interest in this approach, there are few studies where this approach is applied (Grant et al., 2012).

Constructed on three main dynamics based on the principles of "do not repair if it not broken", "apply functioning solutions" and "try different solutions instead of insisting on non-functioning solutions", SolutionFocused Brief Group Counseling Approach (SFBC) (Sklare, 1997) is an approach focusing on individual's own resources and resilience. The basic assumption of the approach is that focusing on solution is to direct the client to think and talk about the solutions of their problems instead of thinking about their problems (Gingerich \& Wabeke, 2001).

Another important concept of the study is "automatic thoughts". While Beck conceptualizes the cognitive structure of the individual, he examines cognitions under two main headings, namely automatic thoughts and schemes (Türkçapar, 2018). Introduced by Beck, cognitive therapy suggests a directive and structured approach enabling the client to be active for various mental disorders, while building this construction on basic stones such 
as automatic thought, scheme and beliefs (Arkar, 1993). One study showed that as the automatic thoughts of university students increase, mental health problems also increase (Calvete \& Connor-Smith, 2005).

The participants of the study are emerging adults aged between 18 and 25. These individuals are considered as neither adolescents nor adults (Arnett, 2000). During emerging adulthood, individuals experience more stress and negative emotions compared to individuals in other developmental periods due to unsteadiness, indecision, negativity, seeking identity, transition to adulthood and having many options (Schulenberg \& Zarrett 2005). This age range corresponds to university years for many young people. The young individual in emerging adulthood finds themselves in some challenging experiences and if this is not resolved, this may turn into important mental health problems in the long term (Akın, 2009).

Based on all above-mentioned information, the study aimed to enable participants to realize solution-focused thinking and behavior and to decrease their automatic thoughts by the solution-focused brief group counseling program (SFBGCP) developed and applied by the researcher. The hypotheses of the study are:

1. There will be a statistically significant increase in the Solution-Focused Inventory total and subscale (problem disengagement, goal orientation, resource activation) scores of the experimental group who participated in the SFBGCP compared to the participants in the control and placebo group. There will be a significant decrease in the Automatic Thoughts Questionnaire. This decrease will also be evident in the follow-up measurements that will be administered four months after the completion of the program.

2. Compared to the participants in the control and placebo group, there will be a significant difference between the Problem Disengagement subscale pretest-posttest scores of the experimental group participants taking part in the SFBGCP in favor of the posttest and between their the posttest and follow-up-test scores in favor of the follow-up test.

3. Compared to the participants in the control and placebo group, there will be a significant difference between the Goal Orientation subscale pretest-posttest scores of the experimental group participants taking part in the SFBGCP in favor of the posttest and between their the posttest and follow-up-test scores in favor of the follow-up test. 
4. Compared to the participants in the control and placebo group, there will be a significant difference between the Resource Activation subscale pretest-posttest scores of the experimental group participants taking part in the SFBGCP in favor of the posttest and between their the posttest and follow-up-test scores in favor of the follow-up test.

5. Compared to the participants in the control and placebo group, there will be a significant difference between the total scale pretest-posttest scores of the experimental group participants taking part in the SFBGCP in favor of the posttest and between their the posttest and follow-uptest scores in favor of the follow-up test.

6. Compared to the participants in the control and placebo group, there will be a significant difference between the Automatic Thoughts Questionnaire pretest-posttest scores of the experimental group participants taking part in the SFBGCP in favor of the posttest and between their the posttest and follow-up-test scores in favor of the follow-up test.

SFBGCP developed by the researcher within the scope of this study is a program based on solution-focused therapy theory. A total of six sessions were developed, each session being 60-90 minutes. The program was developed in order to ensure that participants gain awareness of their emotions, thoughts and behaviors, to achieve their behavioral goals set at the first session, and to achieve their goals by carrying out practices towards increasing their change and development. With the placebo group, participants' recommendations and comments about the deficiencies, wishes and needs in their trainings were discussed. The sessions lasted about 60 minutes and consisted of six sessions. No work was done with the control group.

For the study findings, experimental group participants taking part in the SFBGCP and participants in the control and placebo group were compared. According to the study findings, there were significant differences between the Automatic Thoughts Questionnaire (ATQ) pretest-posttest mean scores in favor of the experimental group. These findings indicate that SFBGCP is effective in decreasing the automatic thoughts scores of the students in the experimental group.

Furthermore, SFBGCP also shows that it is effective in increasing Solution-Focused Inventory (SFI) total scores and its three subscale (problem disengagement, goal orientation, resource activation) scores of the students in the experimental group. In the study, the SFBGCP, which produced posi- 
tive results, was effective in decreasing automatic thoughts of the students and increasing their tendency to be solution-oriented.

\section{Kaynakça / References}

Akın, A. (2010). Self-compassion and interpersonal cognitive distortions. Hacettepe Üniversitesi Ĕ̆itim Fakültesi Dergisi, 39(39), 1-9.

Arkar, H. (1992). Beck'in depresyon modeli ve bilişsel terapisi. Düşünen Adam: Psikiyatri ve Nörolojik Bilimler Dergisi, 5(1-3), 37-40.

Arnett, J. J. (2000). Emerging adulthood: A theory of development from the late teens through the twenties. American Psychologist, 55(5), 469.

Atasayar, M., ve Bilgin, O. (2010). Sınav kaygısı ile baş etmeye yönelik çözüm odaklı grupla psikolojik danışma programı. III. Uygulamalı PDR Kongresi (10-12 Aralik), Ankara.

Atasayar, M., Bilgin, O., ve Berberoğlu, G. (2010). Kısa süreli çözüm odaklıyaklaşım ve aile içi iletişimi arttırmaya yönelik psiko-eğitim çalışması. III. Uygulamal PDR Kongresi (10-12 Aralk), Ankara.

Ateş, B. (2015). Üniversite öğrencilerinin güvengenlik becerileri üzerinde çözüm odaklı grupla psikolojik danışmanın etkisi. Mersin Universitesi Eğitim Fakültesi Dergisi, 11, 832-841.

Ateş, B. (2014). Üniversite öğrencilerinin sosyal fobi ile başa çikmalarinda çözüm odakli grupla psikolojik danişmanin etkisinin incelenmesi. Yayımlanmamış Doktora Tezi. Atatürk Üniversitesi Eğitim Bilimleri Enstitüsü. Erzurum.

Aydın, G., ve Aydın, O. (1990). Otomatik düşünceler ölçeğinin geçerlik ve güvenirliği. Psikoloji Dergisi, 7(24), 51-55.

Beck, A.T. (1976). Cognitive therapy and the emotional disorders. (Çev. A. Türkcan, V. Öztürk), Bilişsel Terapi ve Duygusal Bozukluklar. Litera Yayıncllk, İstanbul, 2008.

Beck, J.S. (2001). Bilişsel terapi: Temel ilkeler ve ötesi. (Çev. Ed. F Balkaya, A İlden Koçkar), Türk Psikologlar Derneği Yayınları, Ankara, 2006.

Beck, A. T. (Ed.). (1979). Cognitive therapy of depression. Guilford press.

Beck, A. T., Brown, G., Steer, R. A., Eidelson, J. I., ve Riskind, J. H. (1987). Differentiating anxiety and depression: A test of the cognitive contentspecificity hypothesis. Journal of Abnormal Psychology, 96(3), 179.

Beck, J. S., ve Beck, A. T. (1995). Cognitive therapy: Basics and beyond. New York: Guilford press.

Beck, J. S. (1995). Cognitive therapy: basics and beyond. New York: The Guilford Press. 
Beck, A.T. ve Haigh, E.A. (2014). Advances in cognitive theory and therapy: The generic cognitive model. Annuel Review of Clinical Psychology. 10 (1-24).

Akın, A. (2009). Self-compassion and Submissive Behavior. Eğitim ve Bilim, 34(152), 138-174.

Bilge, A., ve Engin, E. (2016). Kisilerarasi iliskiler kurami temelli çözüm odakli terapinin etkinligi: Geriye dönük bir inceleme/Effectiveness of the solution focused therapy which is based on interpersonal relationship theory: retrospective investigation. Anadolu Psikiyatri Dergisi, 17(4), 261.

Bowen, S., Witkiewitz, K., Dillworth, T. M., ve Marlatt, G. A. (2007). The role of thought suppression in the relation between mindfulness meditation and alcohol use. Addictive Behaviours, 32, 2324-2328.

Bower, G. H. (1981). Mood and memory. American Psychologist. 36 (2). 129-148.

Bowers, J. W., Metts, S. M., ve Duncanson, W. (1985). Emotion and interpersonel communication. J. Knapp \& G. Miller (Ed.), Handbook of interpersonel communication, Beveryl Hills: CA. Sage.

Bulduk, S. 2003. Psikolojide deneysel araştırma yöntemleri. İstanbul: Çantay Kitabevi.

Bulut Serin, N. ve Derin, R. (2008). İlköğretim öğrencilerinin kişilerarası problem çözme becerisi algıları ve denetim odağı düzeylerini etkileyen faktörler. Uluslararasi Insan Bilimleri Dergisi, 5 (1), 1-18.

Büyüköztürk, S. (2007). Sosyal bilimler için veri analizi el kitabı. Ankara: Pegem A Yayıncilik.

Calvete, E., ve Connor-Smith, J. K. (2005). Automatic thoughts and psychological symptoms: A cross-cultural comparison of American and Spanish students. Cognitive Therapy and Research, 29(2), 201-217.

Carr, S. M., Smith, I. J., ve Simm, R. (2013). Solution-focused brief therapy from the perspective of clients with long-term physical health conditions. Psychology Health and Medicine. 19(4), 384-391.

Cho, H., Ryu, S., Noh, J., ve Lee, J. (2016). The effectiveness of daily mindful breathing practices on test anxiety of students. PloS one, 11(10), e0164822.

Christie, H., Tett, L., Cree, V. E., Hounsell, J., ve McCune, V. (2008). 'A real rollercoaster of confidence and emotions': Learning to be a university student. Studies in Higher Education, 33(5), 567-581.

Corcoran, J. (2006). A comparison group study of solution- focused therapy versus treatment as usual for behavior problems in children. Journal of Social Service Research, 33(1), 69-81. 
Corey, C. (2008). Psikolojik danışma, psikoterapi kuram ve uygulamaları. Ankara: Mentis Yayınları.

Corey, G. (2005). Psikolojik danışma, psikoterapi kuram ve uygulamaları, Çev. T. Ergene, Ankara:mentis yayınları.

Coyne, J. C., ve Gotlib, I. H. (1983). The role of cognition in depression: a critical appraisal. Psychological Bulletin, 94(3), 472-505.

Daki, J., \& Savage, R. S. (2010). Solution-focused brief therapy: Impacts on academic and emotional difficulties. The Journal of Educational Research, 103(5), 309-326.

Davies, E. B., Morriss, R., ve Glazebrook, C. (2014). Development and usability of a website-based depression literacy intervention for university students in Nottingham. Division of Psychiatry \& Applied Psychology, The University of Nottingham, Nottingham, UK.

Davison, G.C. ve Neale J.M. (1998) Anormal psikolojisi (Çev. Ed. İ Dağ). Ankara:Türk Psikologlar Derneği Yayınları, 2004.

Demirci, İ., ve Erden, S. (2016). Bilişsel davranışçı yaklaşıma dayalı grupla psikolojik danışma uygulamasının 8. sınıf öğrencilerinin sınav kaygısına etkisi. Marmara Üniversitesi Atatürk Ĕ̆itim Fakültesi Eğitim Bilimleri Dergisi, 43(43), 67-83.

Der Pan, P. J., Deng, F. L. Y., Tsai, S. L., ve Yuan, S. J. (2015). Using Kollar's solution-focused pastoral counseling for bereaved clients: The process of empowerment from clients' perception. Psychological Reports, 116(1), 127-148.

Doğan, S. (1999). Çözüm-odaklı kısa süreli terapi: Kuramsal bir inceleme. Türk Psikolojik Danışma ve Rehberlik Dergisi, 2(12), 23-38.

Doğan, S. (2000). Okul psikolojik danışmanları için yeni ve pratik bir yaklaşım: Çözüm odaklı kısa süreli psikolojik danışma. Eğitim ve Bilim Dergisi. 25(116), 59-64.

Duarte, P. S., Miyazaki, M. C., Blay, S. L., ve Sesso, R. (2009). Cognitivebehavioral group therapy is an effective treatment for major depression in hemodialysis patients. Kidney International, 76(4), 414-421.

Dutton, D. G., \& Karakanta, C. (2013). Depression as a risk marker for aggression: A critical review. Aggression and Violent Behavior, 18(2), 310-319.

Eisenberg, D., Gollust, S. E., Golberstein, E., ve Hefner, J. L. (2007). Prevalence and correlates of depression, anxiety, and suicidality among university students. American journal of Orthopsychiatry, 77(4), 534-542. 
Eisenberg, N., Gershoff, E. T., Fabes, R. A., Shepard, S. A., Cumberland, A. J., Losoya, S. H., ... ,Murphy, B. C. (2001). Mother's emotional expressivity and children's behavior problems and social competence: Mediation through children's regulation. Developmental Psychology, 37(4), 475.

Franklin, C., Moore, K., ve Hopson, L. (2008). Effectiveness of solution-focused brief therapy in a school setting. Children $\mathcal{E}$ Schools. 30(1),15-26.

George, M. C. (2008). Solution-focused therapy: Strength-based counseling for children with social phobia. Journal of Humanistic Counseling, Education Development. 47, 144-156.

Gingerich, W. J., ve Peterson, L. T. (2013). Effectiveness of solution-focused brief therapy: A systematic qualitative review of controlled outcome studies. Research on Social Work Practice, 23(3), 266-283.

Gingerich, W. J., ve Wabeke, T. (2001). A solution-focused approach to mental health intervention in school settings. Children \& Schools, 23(1), 33-47.

Grant, A. M. (2011). The solution-focused inventory: A tripartite taxonomy for teaching, measuring and conceptualising solution-focused approaches to coaching. The Coaching Psychologist, 7(2), 98-106.

Grant, A. M. , Cavanagh, M. J. , Kleitman, S. , Spence, G. , Lakota, M. ve Yu, N. (2012). Development and validation of the solution-focused inventory. The Journal of Positive Psychology. 7(4), 334-348.

Grant, A. M. (2008). Personal life coaching for coaches-in-training enhances goal attainment and insight, and deepens learning. Coaching: An International Journal of Research. Theory and Practice. 1(1), 47-52.

Grant, A. M. (2013). Steps to Solutions: A process for putting solution-focused coaching principles into practice. The Coaching Psychologist, 9(1), 36-44.

Grant, A. M., ve O'Connor, S. A. (2010). The differential effects of solutionfocused and problem-focused coaching questions: A pilot study with implications for practice. Industrial and Commercial Training, 42(2), 102111.

Gruber, K., Moran, P. J., Roth, W. T., ve Taylor, C. B. (2001). Computer-assisted cognitive behavioral group therapy for social phobia. Behavior Therapy, 32(1), 155-165.

Haaga, T.,Dyck, M. ve Ernst, D. (1991). Empirical status of cognitive theory of depression. Psychological Bulletin. 110 (2).

Hefferon, K., ve Boniwell, I. (2011). Positive psychology: Theory, research and applications. McGraw-Hill Education (UK). 
Hiçdurmaz, Ö. G. D. D., ve Öz, F. (2011). Benliğin bilişsel yaklaşımla güçlendirilmesi. Hacettepe Üniversitesi Hemşirelik Fakültesi Dergisi, 18(2), 68-78.

Hinton, M. J., ve Gaynor, S. T. (2010). Cognitive defusion for psychological distress, dysphoria, and low self-esteem: A randomized technique evaluation trial of vocalizing strategies. International Journal of Behavioral Consultation and Therapy, 6(3), 164.

Hollon, S. D., ve Kendall, P. C. (1980). Cognitive self-statements in depression: Development of an automatic thoughts questionnaire. Cognitive Therapy and Research, 4(4), 383-395.

Hosseinpour, N., Jadidi, M., Mirzaian, B., ve Hoseiny, H. (2016). The efficiency of solution-focused brief therapy on adjustment problems of female students in Amol, Iran. International Journal of School Health, 3(1).

Iveson, C. (2002). Solution-focused brief therapy. Advances in Psychiatric Treatment, 8,149-157.

İlbay, A.B. (2014). Çözüm odaklı kısa süreli grupla psikolojik danışmanın üniversite öğrencilerinin tükenmişlik düzeyleri üzerindeki etkisi. Yayımlanmamış doktora Tezi. Sakarya Üniversitesi, Eğitim Bilimleri Enstitüsü. Sakarya.

İşlek, M. (2006). Çözüm odakl yaklaşıma göre düzenlenmiş s ınav kaygısıyla başa çıkma eğitim programının üniversiteye hazırlanan öğrencilerin sınav kaygısı düzeylerine etkisi. Yayımlanmamış yüksek lisans tezi. Hacettepe Üniversitesi Sosyal Bilimler Enstitüsü, Ankara.

Jain, S., Shapiro, S. L., Swanick, S., Roesch, S. C., Mills, P. J., Bell, I., ve Schwartz, G. E. (2007). A randomized controlled trial of mindfulness meditation versus relaxation training: effects on distress, positive states of mind, rumination, and distraction. Annals of Behavioral Medicine, 33(1), 11-21.

Karahan, F. Ş., ve Hamarta, E. (2015). Çözüm odaklı envanter: Güvenirlik ve geçerlik çalışması. İlköğretim Online, 14(2).

Kim, J. S. (2008). Examining the effectiveness of solution-focused brief therapy: A meta-analysis. Research on Social Work Practice, 18(2), 107-116.

Kiser, D. J., Piercy, F. P., ve Lipchik, E. (1993). The integration of emotion in solution-focused theapy. Journal of Marital and Family Therapy, 19(3), 233-242.

Köktuna, Z. S. (2007). Çözüm odaklı kısa terapi tekniğinin alt sosyo-ekonomik seviyedeki kadınların geleceğe umut ile bakabilme ve boyun eğici davranışlarına etkisinin incelenmesi. Yayımlanmamış Yüksek Lisans Tezi. Maltepe Üniversitesi Sosyal Bilimler Enstitüsü, İstanbul. 
Kramer, J., Conijn, B., Oijevaar, P., ve Riper, H. (2014). Effectiveness of a webbased solution-focused brief chat treatment for depressed adolescents and young adults: Randomized controlled trial. Journal of Medical Internet Research. 16(5), 141-153.

Lappalainen, P., Langrial, S., Oinas-Kukkonen, H., Tolvanen, A., ve Lappalainen, R. (2015). Web-based acceptance and commitment therapy for depressive symptoms with minimal support: a randomized controlled trial. Behavior Modification, 39(6), 805-834.

Lindforss, L., \& Magnusson, D. (1997). Solution-focused therapy in prison. Contemporary Family Therapy, 19(1), 89-103.

Lipchik, E. (1999). Theoretical and practical thoughts about expanding the solution-focused approach to include emotions. Evolving brief therapy: In honor of John H. Weakland, içinde (s.157-177). Gelena, IL: Geist \& Russell.

MacDonald, A. J. (2007). Solution-focused therapy: Theory, Research and Practice (1st Ed.). London: Sage Publications Inc.

Mercan, Ç. S., ve Yavuzer, H. (2007). Bilişsel-davranışçı yaklaşımla bütünleştirilmiş sosyal beceri eğitiminin ergenlerin sosyal kaygı düzeyine etkisi. Elektronik Sosyal Bilimler Dergisi, 16(63), 1187-1202.

Meriç, M., ve Oflaz, F. (2013). Anksiyete bozukluğu olan hastalarda bilişsel yaklaşım temelli hemşirelik uygulamasının hastaların tedaviyle ilgili otomatik düşünceleri üzerine etkisi. Psikiyatri Hemşireleri Dernegi, 4(3), 109118.

Meydan, B. (2013). Çözüm odaklı kısa süreli psikolojik danışma: Okullardaki etkililiği üzerine bir inceleme. Türk Psikolojik Danışma ve Rehberlik Dergisi, 4(39), 120-129.

Miller, G., ve De Shazer, S. (2000). Emotions in solution-focused therapy: A reexamination. Family Process, 39(1), 5-23.

Murdock, N. L. (2016). Psikolojik damışma ve psikoterapi kuramları. (F. Akkoyun, Çev. Edt.) Ankara: Nobel Yayınevi.

Norton, P. J. (2008). An open trial of a transdiagnostic cognitive-behavioral group therapy for anxiety disorder. Behavior Therapy, 39(3), 242-250.

O'Connell, B. (2001). Solution-focused stress counselling. London: Continuum.

Perry, C. (2014). Solution focused brief therapy applied to diverse classroom settings in a Four-Year University. Creative Education. 5(22), 1943-1946.

Piercy, F. P., Lipchik, E., ve Kiser, D. (2000). Miller and de Shazer's article on "emotions in solution-focused therapy". Family Process, 39(1), 25-28. 
Purdon, C., ve Clark, D. A. (2005). Overcoming obsessive thoughts: How to gain control of your OCD. New Harbinger Publications.

Quick, E. K. (1996). Doing what works in brief therapy: A strategic solution-focused approach. San DiegoCalifornia: Academic Press.

Radhu, N., Daskalakis, Z. J., Arpin-Cribbie, C. A., Irvine, J., ve Ritvo, P. (2012). Evaluating a web-based cognitive-behavioral therapy for maladaptive perfectionism in university students. Journal of American College Health, 60(5), 357-366.

Ramel, W., Goldin, P. R., Carmona, P. E., \& McQuaid, J. R. (2004). The effects of mindfulness meditation on cognitive processes and affect in patients with past depression. Cognitive therapy and research, 28(4), 433-455.

Reddy P.D., Thirumoorthy, A., Vijayalakshmi, P., ve Hamza, M.A. (2015). Effectiveness of solution-focused brief therapy for an adolescent girl with moderate depression. Indian J Psychol Med. 37(1), 87-97.

Reimer, W. L., ve Chatwin, A. (2006). Effectiveness of solution focused therapy for affective and relationship problems in a private practice context. Journal of Systemic Therapies, 25(1), 52-67.

Rhodes, J., \& Jakes, S. (2002). Using solution-focused therapy during a psychotic crisis: a case study. Clinical Psychology \& Psychotherapy, 9(2), 139-148.

Ritvo, P., Vora, K., Irvine, J., Mongrain, M., Azargive, S., Abid Azam, M., ve Cribbie, R. A. (2013). Reductions in negative automatic thoughts in students attending mindfulness tutorials predicts increased life satisfaction. International Journal of Educational Psychology, 2(3), 272-296.

Rothwell, N. (2005). How brief is solution focussed brief therapy? A comparative study. Clinical Psychology \& Psychotherapy: An International Journal of Theory \& Practice, 12(5), 402-405.

Sapmaz, F. (2011). Bilişsel davranışçı yaklaşıma dayalı grupla psikolojik danışmanın sosyal anksiyete, reddedilme duyarlılı̆̆ı ve kişilerarası duyarlılı üzerine etkisi. Yayımlanmamış Doktora Tezi. Sakarya Üniversitesi, Eğitim Bilimleri Enstitüsü, Sakarya.

Sarıcı Bulut, S. (2008). İlköğretim ikinci kademe öğrencilerinin sınav kaygıları, saldırganlık eğilimleri ve problem çözme becerilerindeki yetersizliklerin sağaltımlarında grupla çözüm odaklı kısa terapinin etkileri. Yayınlanmamış Doktora Tezi, Atatürk Üniversitesi, Sosyal Bilimler Enstitüsü, Erzurum.

Sarıçam, H. (2014). Çözüm odaklı kısa süreli yaklaşıma dayalı bir müdahale programının ruminasyon üzerinde etkisi. Yayımlanmamış doktora Tezi. Sakarya Üniversitesi, Eğitim Bilimleri Enstitüsü. Sakarya. 
Savasir, I. and Sahin, N.H. (1997) Bilişsel-davranışçı terapilerde degerlendirme: Sık kullanılan ölçekler. Türk Psikologlar Dernegi Yayınları, Ankara, 23-38.

Savaşır, I., Soygüt, G., ve Kabakçı, E. (2003). Bilişsel-davranışçı terapiler. (3. Baskı). Ankara: Türk Psikologlar Derneği Yayınları.

Sertelin, M. Ç. Ve Yavuzer, H. (2017). Bilişsel davranışçı yaklaşımla bütünleştirilmiş sosyal beceri eğitiminin ergenlerin sosyal kaygı düzeyine etkisi, Elektronik Sosyal Bilimler Dergisi. 16 (63). 1187-1202.

Sertelin, M. Ç. (2007). Bilişsel- davranışçı yaklaşımla bütünleştirilmiş sosyal beceri eğitiminin ergenlerin sosyal kaygı düzeyine etkisi. Yayımlanmamış Doktora Tezi. İstanbul Üniversitesi, Sosyal Bilimler Enstitüsü. İstanbul.

Schulenberg, J.E. ve Zarrett, N.R. (2005). Mental health during emerging adulthood: Continuity and discontinuity in courses, causes, and functions. American Psychological Association-Washington.

Seidel, A., ve Hedley, D. (2008). The use of solution-focused brief therapy with older adults in Mexico: A preliminary study. The American Journal of Family Therapy, 36(3), 242-252.

Seligman, L. (2006). Theories of counseling and psychotherapy: Systems, strategies, and skills. Upper Saddle River, New Jersey: Pearson Education Inc.

Sharf, R. S. (2017). Psikoterapi ve psikolojik danışma kuramları: Kavramlar ve örnek olaylar. Nobel Yayın.

Sharry, J., Darmody, M., ve Madden, B. (2002). A solution-focused approach to working with clients who are suicidal. British Journal of Guidance and Counselling, 30(4), 383-399.

Sklare, G. B. (1997). Brief counseling that works: A solution-focused approach for school counselors. California: Corwin Pres, Inc.

Smith, S. (2010). A preliminary analysis of narratives on the impact of training in solution-focused therapy expressed by students having completed a 6month training course. Journal of Psychiatric and Mental Health Nursing. 17(2). 105-115.

Soygut, G. (2003). Yeme bozukluklarında bilişsel davranış̧̧ı tedaviler. I., Savaşır, G., Soygüt, E., Kabakçı (Ed). III. Baskı. Bilişsel Davranışçı Terapiler. Ankara: Turkish Psychological Association Press.

Spilsbury, G. (2012). Solution-focused brief therapy for depression and alcohol dependence: A case study. Clinical Case Studies, 11(4), 263-275.

Steer, R. A., Clark, D. A., Beck, A. T., ve Ranieri, W. F. (1995). Common and specific dimensions of self-reported anxiety and depression: A replication. Journal of Abnormal Psychology, 104(3), 542. 
Suldo, S. M., Riley, K., ve Shaffer, E. S. (2006). Academic correlates of children and adolescents' life satisfaction. School Psychology International. 27, 567582.

Sütcü, S. T., Aydın, A., ve Sorias, O. (2010). Ergenlerde öfke ve saldırganlığ1 azaltmak için bilişsel davranışçı bir grup terapisi programının etkililiği. Türk Psikoloji Dergisi, 25(66), 57-67.

Şahin, N. H., ve Şahin, N. (1992). Adolescent guilt, shame, and depression in relation to sociotropy and autonomy. The World Congress of Cognitive Therapy, içinde (s. 17-21). Toronto

Taube-Schiff, M., Suvak, M. K., Antony, M. M., Bieling, P. J., ve McCabe, R. E. (2007). Group cohesion in cognitive-behavioral group therapy for social phobia. Behaviour Research and Therapy, 45(4), 687-698.

Thienemann, M., Martin, J., Cregger, B., Thompson, H. B., ve Dyer-Friedman, J. (2001). Manual-driven group cognitive-behavioral therapy for adolescents with obsessive-compulsive disorder: A pilot study. Journal of the American Academy of Child \& Adolescent Psychiatry, 40(11), 1254-1260.

Tuna, D. (2012). Çözüm odaklı kısa süreli yaklaşıma dayalı öfke kontrolü eğitim programının lise öğrencilerinin öfke kontrolü ve iletişim becerileri düzeylerine etkisi. Yayımlanmamış yüksek lisans tezi. Dokuz Eylül Üniversitesi Eğitim Bilimler Enstitüsü, İzmir.

Tümkaya, S., ve İflazoğlu, U. A. (2000). Sınıf öğretmenliği öğrencilerinin otomatik düşünce ve problem çözme düzeylerinin bazı sosyo demografik değişkenlere göre incelenmesi. Çukurova Üniversitesi Sosyal Bilimler Enstitüsü Dergisi, 6(6), 143-158.

Türkçapar, H. M. (2018). Bilişsel davranış̧ı terapi temel ilkeler ve uygulama. Epsilon Yayıncilık. İstanbul.

Türkçapar, H. M. (2014). Bilişsel terapi. Boylam Yayınları, 7.Baskı. Ankara.

Utterback, M. Z. (2011). Supporting latino first-generation community college transfer students: an approach using solution-focused brief therapy and validation technique. Unpublish master of thesis. Saint Mary's College of California.

Valve P, Lehtinen-Jacks S, Eriksson T, Lehtinen M, Lindfors P, Saha MT, Rimpelä, A., ve Anglé, S. (2013). Linda-a solution- focused low-intensity intervention aimed at improving health behaviors of young females: a cluster-randomized controlled trial. BMC Public Health. 4(13). 1044. 
Varol, C., Karakaş, S., ve Bedel, A. (2015). Stresle başa çıkma eğitiminin üniversite öğrencilerinin stresle başa çıkma tarzlarına ve otomatik düşüncelerine etkisi. Internatıonal Journal of Eurasia Socıal Sciences Dergisi, 6(19), 7691.

Walter, J. L. ve Peller, J. E. (1992). Becoming solution-Focused in brief counseling. NewYork: Brunner-Mazel.

Weiner-Davis, M. (1996). Change your life and everone In It. Fireside Book, New York: Simon and Schuster.

Wiveka, R., Philippe, R. G., Carmona, P.E, McQuaid, J. R. (2004). The effects of mindfulness meditation on cognitive processes and affect in patients with past depression. Cognitive Therapy and Research. 28(4). 433-455.

Yuan, K., Qin, W., Wang, G., Zeng, F., Zhao, L., Yang, X., Liu, P., ..., Tian, J. (2011). Microstructure abnormalities in adolescents with Internet addiction disorder. PLoS One, 6(6), Crossref, Medline.

Zhang, A., Franklin, C., Currin-McCulloch, J., Park, S., ve Kim, J. (2018). The effectiveness of strength-based, solution-focused brief therapy in medical settings: a systematic review and meta-analysis of randomized controlled trials. Journal of Behavioral Medicine, 41(2), 139-151.

\section{Kaynakça Bilgisi / Citation Information}

Gündoğdu, R. (2020). Psikolojik danışman adaylarıyla çözüm odaklı grupla psikolojik danışmanın çözüm odaklı eğilim ve otomatik düşüncelere etkisi. OPUS-Uluslararası Toplum Araştırmaları Dergisi, 15(10. Y1l Özel Say1s1), 5149-5196. DOI: 10.26466/opus.693205 